\title{
Payments for ecosystem services and motivational crowding in Colombia's Amazon Piedmont
}

\author{
Lina Moros ${ }^{\mathrm{a}}$, María Alejandra Vélez ${ }^{\mathrm{b}}$, Esteve Corbera ${ }^{\mathrm{a}, *}$ \\ a Institute of Environmental Science and Technology (ICTA), Universitat Autònoma de \\ Barcelona, Spain \\ b School of Management, Universidad de los Andes, Colombia \\ * Corresponding author. E-mail address: esteve.corbera@uab.cat (E. Corbera).
}

\begin{abstract}
Globally, there is an increasing level of funding targeted to pay farmers and rural communities for the provision of ecosystem services, for example through Payments for Ecosystem or Environmental Services (PES) schemes and pilots for Reducing Emissions from Deforestation and forest Degradation, and maintaining or enhancing forest carbon stocks (REDD+). Therefore, there is growing interest in understanding the effects of economic incentives on participants' behavior and motivations. We adopt here an innovative research design to test for motivational crowding effects through a forest conservation game in Colombia's Amazon Piedmont, using individual, collective and crop-price premium economic incentives. We implement a post-experiment survey on different types of motivations based on Self-Determination Theory (SDT) to test for changes in motivations. Our findings show that all types of PES, except for the crop-price premium payment, increased conservation behavior in the experiment. However, not all types of payments affected motivations equally: collective payments enhanced social motivations to protect forests and the crop-price premium reduced intrinsic and guilt/regret related motivations. These findings contribute to disentangling the interaction between incentives, motivations and behaviors in a context of agricultural expansion and growing concern for forest conservation.
\end{abstract}

\section{Key words}

Ecosystem services, Payments, Experiment, Motivational Crowding, Colombia 


\section{Introduction}

Environmental science and policy is increasingly interested in understanding if conservation initiatives that use direct monetary incentives to promote pro-environmental behaviors can unwillingly result in a "crowding-out" effect. The latter would imply either an alteration or substitution of intrinsic motivations to protect and sustainably manage the environment by extrinsic and more instrumental motivations (Gómez-Baggethun et al., 2010; Kosoy \& Corbera, 2010; Pascual et al., 2010; Wunder, 2013). Understanding this alleged effect is relevant because increasing levels of international and national funding are channeled to pay farmers and communities to support pro-environmental behavior (e.g. Payments for Ecosystem or Services at local and global scales) ${ }^{1}$, which in turn sparks a growing concern over the temporal stability of such behaviors once economic incentives are removed (Fisher, 2012).

In this article, we investigate the relationship between motivational crowding, types of motivations, and the specific features of a simulated scheme of Payments for Ecosystem or Environmental Services (PES) in Colombia's Amazon Piedmont. PES usually involve the transfer of direct economic incentives to individuals and communities in exchange of specific or bundled ecosystem services, usually provided through sustained forest and biodiversity conservation activities. PES schemes emerged in the late 1990s as a policy tool to tackle deforestation and unsustainable resource use, and to maintain or provide specific ecosystem services (Engel et al., 2008), while payment conditionality was alleged to guarantee the provision of such services over time (Sommerville et al., 2010). Given their potential to involve less resource use restrictions relative to other conservation measures such as protected areas (Pagiola et al., 2005), PES have been widely promoted and implemented as an incentive for conservation in Latin America, Asia, and Africa (Grima et al., 2016).

The largest PES schemes worldwide have been often designed and implemented by governments, following a subsidy-like approach that targets specific ecosystems and mostly rural communities, while smaller initiatives have been brokered by NGOs and international donors, sometimes with the backing of national or sub-national governments (Engel, 2016; Muradian et al., 2013; Vatn, 2010). Most PES initiatives have delivered direct cash payments per hectare targeted at farmers or social groups, and very few have rewarded providers in-kind, either individually (e.g. individual beehives or barbed wire) or collectively (e.g. through the improvement of public goods) (Asquith et al., 2008). Such diversity of PES schemes reflects the flexibility of the policy tool to adjust to specific contexts and needs, but it also entails analytical challenges when aiming to compare and assess their environmental effectiveness (Börner et al., 2017) and their

\footnotetext{
${ }^{1}$ As an example, Colombia recently launched the Visión Amazonía project, which will invest US\$200 million (50\% donated by international donors) until 2020 to halt deforestation processes completely. This project will be based on direct payments to landholders, and complemented by the BIOREDD+ program in Colombia, which aims to invest an additional US\$27,8 million to promote sustainable livelihoods compatible with forest conservation.
} 
contribution to human well-being (Alix-Garcia et al., 2015; Arriagada et al., 2012; CalvetMir et al., 2015).

People's motivations to participate in PES have been qualitatively explored asking participants their reasons and perceived barriers to engage in such initiatives. In different countries, both instrumental (e.g. increasing household income) and non-instrumental reasons (e.g. maintaining forests' non-provisioning services) have been reported as key participation drivers (Bremer et al., 2014; Grillos, 2017; Hendrickson \& Corbera, 2015; Kosoy et al., 2008; Pagiola et al., 2005). However, very few studies have addressed the possible effects of payments on motivations over time (Fisher, 2012).

To understand such possible effects, we draw on Ryan and Deci's (2000) SelfDetermination Theory (SDT) and build on the scarce research that has investigated motivational crowding in PES (Handberg \& Angelsen, 2016; Kaczan et al., 2016; Midler et al., 2015; Narloch et al., 2012; Salk et al., 2016; Vollan, 2008). Most of these studies use controlled economic experiments to recreate real life, individual decision-making dilemmas. In addition, these studies have, at least implicitly, equated motivational crowding to changes in individuals' behavior. However, we sustain that concluding that changes in behavior between experimental rounds are equivalent to motivational crowding is probably inaccurate, since observed behaviors in experiments may change after the introduction of an incentive while motivations may remain unchanged or their change might be lagged in time (Young, 1986). Furthermore, social psychology has noted that motivations and behavior might not necessarily be aligned, and it has asserted that although motivations precede behaviors, the former can be shaped by institutions and previous behaviors (Agrawal, 2005; Steg \& Vlek, 2009; Schulter et al. 2017)

To take into account this possible misalignment between motivations and behavior, we introduce in our research design a post-experiment survey to observe if different types of payments during an economic experiment have an impact on participants' intrinsic and extrinsic motivations to protect forests. The survey allows us to distinguish between changes in behavior and changes in different types of motivations. Furthermore, it allows us to attribute any changes in survey responses to participation in the experiment while controlling for observable variables. Therefore, we understand crowding out as any reduction in pro-environmental motivations across control versus treatment experimental groups.

In what follows, we present a brief literature review on pro-environmental motivations and motivational crowding. Section three justifies the choice of the study site and section four presents our methodological approach. Section five discusses the results in the context of existing literature and the article concludes with a summary of findings and recommendations for future PES design. 


\section{Literature on motivations and experimental evidence}

\subsection{Motivational and crowding-out theories}

A general definition of motivation is "to be moved to do something" (R. Ryan \& Deci, 2000), and motivation is thus a driving force of human behaviour. We draw here on the Self-Determination Theory (SDT) as proposed by Ryan and Deci (Ryan \& Deci, 1985; Ryan et al., 2000) ${ }^{2}$ because of its predictive power and the fact that it distinguishes across types of motivational processes (Moller et al., 2006). According to SDT, human motivation should be understood as a continuum between two extremes: intrinsic motivation and a-motivation. A person is intrinsically motivated to perform a task when such task is inherently interesting or enjoyable, while a person is a-motivated when she lacks an intention to act. In between, there are four types of extrinsic motivations (i.e. external regulation, introjection, identification and integration) that refer to doing something driven by external reasons (e.g. fear of punishment, avoiding the feeling of guilt or regret) or doing something because it leads to a separable outcome (e.g. money, reputation). These extrinsic motivations vary in their degree of autonomy (the individual's experience of choice) and internalization of external regulations by the individual's values and attitudes.

SDT posits that the process of moving away from or towards intrinsic motivation is determined by the interaction between the external incentive and three psychological moderators (autonomy, feelings of competence, and relatedness). Any incentive, including PES, that undermines an individual's autonomy, perceived confidence on reaching a goal, or her sense of belongingness to a community or social group is expected to crowd-out motivations, moving the individual towards the a-motivation extreme, driven for example by feelings of control aversion or frustration. In contrast, any incentive that supports or reinforces these psychological mechanisms is expected to do the opposite (Ezzine-de-Blas et al., in this issue; Rode et al., 2015).

General knowledge on incentives and motivational crowding comes primarily from psychology (Deci et al., 1999; Frey, 1994; Kahneman et al., 2011; Moller et al., 2006; R. Ryan et al., 1985, 2000), behavioral economics (Bowles \& Polanía-Reyes, 2012; Gneezy et al., 2011; Gneezy \& Rustichini, 2000) and public policy literature (Ariely et al., 2009; Dolan et al., 2011; Le Grand, 2006; Thaler \& Sunstein, 2008; Titmuss, 1970). A common reported result in this literature is a negative effect of tangible rewards on intrinsic motivations. In the environmental policy domain, a review of 18 articles that tested for motivational crowding concludes that crowding-out effects are more often reported than crowding-in (Rode et al., 2015). However, the authors emphasize that some of the reviewed articles are unclear in their use of the term "motivation", which is often used interchangeably with social norms, pro-social behaviors and even emotions (e.g. guilt,

\footnotetext{
2 There are other theories about motivation, including e.g. the Two-Factor theory (Herzberg, 1965)the Expectancy value theory (Vroom, 1964)or the Self-efficacy theory (Bandura, 1977)
} 
shame). This is not a minor caveat, since contributions from environmental psychology suggest that these are different concepts (Steg et al., 2014).

\subsection{Motivations in environmental studies}

In environmental psychology there is a prolific debate focused on disentangling the relationship between attitudes, values, beliefs, motivations and pro-environmental behaviors in urban settings (De Groot \& Steg, 2008; Lindenberg \& Steg, 2007; Steg, 2016; Young, 1986). Motivations are hereby understood as the reasons to engage in behaviors that benefit the environment (Steg et al., 2014, 2009). Different theories of proenvironmental behavior have developed their own instruments to capture the reasons people have to behave in an environmentally friendly manner, being the Environmental Motives Scale -EMS- (Schultz, 2000) the New Ecological Paradigm Scale -NEP(Dunlap et al., 2000) and the Motivation Towards the Environment Scale -MTES(Pelletier et al., 1998) the most cited and used.

However, as the set of pro-environmental behaviors is wide, it is no surprise that no single theory is broad enough to explain or predict every pro-environmental behavior (Steg et al., 2009). Additionally, scales are not completely exclusive and there are correlations between them (De Groot \& Steg, 2010). Nonetheless, with different names and labels, in environmental psychology it is commonly accepted that pro-environmental behaviors are guided, in general, by reasons related to pleasure, moral duty and economic gains (Steg et al., 2014).

In the context of environmental conservation initiatives in rural areas, some authors have equated motivations to the set of reasons to engage in specific activities or initiatives, such as community-based conservation initiatives (Ruiz-Mallén et al., 2015; Souto et al., 2014), biodiversity provision contracts (Dedeurwaerdere et al., 2016; Greiner, 2015; Greiner et al., 2009), PES or integrated conservation and development projects (Bremer et al., 2014; Fisher, 2012; Hendrickson et al., 2015; Kosoy et al., 2008; Rico GarcíaAmado et al., 2013), and agri-environmental schemes (Lastra-Bravo et al., 2015; R. L. Ryan et al., 2003). These studies have relied on surveys, ranking exercises or semistructured interviews to capture the factors and drivers of individuals' participation, which can be generally classified in two sometimes overlapping categories: instrumental vs. non-instrumental reasons. Among instrumental reasons, economic benefits derived from ecosystem services or social rewards such as recognition or reputation are included. Non-instrumental reasons include a sense of moral duty, respect for nature and animals, or stewardship ethics (Rode et al., 2015). However, motivation theory guides only a minority of these studies (Ruiz-Mallén et al., 2015) and most of them do not reflect a clear coherence between theory and the methods deployed. Our study addresses directly this gap by directly relying on SDT and MTES frameworks to capture pro-environmental motivations. 


\subsection{Experimental evidence in PES}

Theoretical studies caution about the potential side effects of payments on intrinsic motivations (Corbera et al., 2007; Sommerville et al., 2009) but few have tried to measure these alleged effects. This void might relate to the fact that in order to examine whether PES crowd out other values one should ideally employ a longitudinal research design and be able to to determine causality of outcomes (Fisher, 2012 p.45). To date, two methodological approaches have been employed to address this challenge: quasiexperimental evidence and economic experiments. Grounded on quasi-experimental evidence, Agrawal et al. (2015) find that crowding out of motivations has occurred when participants of an environmental and development project in the Himalayas received private economic incentives while crowding in happened when participants received communal assets or collective benefits. In Cambodia, Chervier et al., (2017) show that PES participants report more money related reasons to protect forests and are more likely to break conservation rules after payments cease compared to a control group.

Studies using decision-making experiments to test for motivational crowding have been often structured around two stages: a first stage that sets the behavioral baseline, i.e. recreating a situation in which no communitarian, governmental or market regulatory mechanisms are implemented to manage forests, and a second stage in which an incentive or regulation is introduced to allow for a comparison of individuals' behavior between phases 1 and 2. Crowding-in happens when the desired environmental behavior in phase 2 (with incentives) is higher than in phase 1 (without incentives), while crowding-out occurs when the opposite is observed. However, as noted earlier, the problem of this approach is to implicitly equate changes in behaviors to changes in motivations, which is problematic given that observed behaviors may change in the experiment but motivations may remain unchanged, or their change might be lagged in time. Hence, the durability of observed behaviors depends on the motivations operating behind (McClelland \& Canter, 1981; Moller et al., 2006; Young, 1993).

Four out of six experimental studies identified find no support for the behavioral crowding-out hypothesis (Handberg et al., 2016; Kaczan et al., 2016; Salk et al., 2016; Vollan, 2008) while the other two (Midler et al., 2015; Narloch et al., 2012) conclude that crowding-out occurs when collective payments are implemented and crowding-in when payments are granted individually (Table 1). Only two of these five studies have added a third stage in which the incentive is removed to test the persistent effects of the incentive (Kaczan et al., 2016; Salk et al., 2016). These studies have been developed in very different institutional contexts, using distinct types of experiments and lack a baseline of motivations, which limit their ability to generalize about both behavioral and motivational crowding in PES. By combining an economic experiment with a motivations-focused survey, our study thus aims to analyze separately motivations and behaviors and provide a more nuanced analysis of the interaction between motivations and behaviors under different types of payments. 
Table 1. A review of experimental economics and quasi-experimental studies measuring motivational crowding. 


\begin{tabular}{|c|c|c|c|c|}
\hline Study & Country & Method & Crowd out & Crowd in \\
\hline 1. Vollan (2008) & $\begin{array}{l}\text { South Africa and } \\
\text { Namibia }\end{array}$ & $\begin{array}{l}\text { Experimental Economics: Common Pool } \\
\text { Resources game-Penalty vs payment// } \\
\text { Controlling vs. Supportive intervention } \\
\text { High vs low self-determination/ trust and } \\
\text { social norms }\end{array}$ & No evidence & No evidence \\
\hline $\begin{array}{l}\text { 2. Agrawal, Chhatre and } \\
\text { Gerber (2015) }\end{array}$ & India & $\begin{array}{c}\text { Quasi-experimental } \\
\text { Before and after } \\
\text { Matching with non-participants }\end{array}$ & $\begin{array}{l}\text { When participants } \\
\text { received private } \\
\text { economic benefits }\end{array}$ & $\begin{array}{l}\text { When participants received } \\
\text { communal assets or } \\
\text { collective benefits }\end{array}$ \\
\hline $\begin{array}{l}\text { 3. Narloch et al. (2012); } \\
\text { Midler et al. (2015) }\end{array}$ & Perú and Bolivia & $\begin{array}{l}\text { Experimental economics: agro biodiversity } \\
\text { game- public goods game with threshold- } \\
\text { individual and collective payments w/wo } \\
\text { communication }\end{array}$ & $\begin{array}{l}\text { Collective payments } \\
\text { crowd out social norms }\end{array}$ & $\begin{array}{l}\text { Individual payments crowd } \\
\text { in social norms }\end{array}$ \\
\hline $\begin{array}{l}\text { 4. Chervier, Le Velly and } \\
\text { Ezzine-de-Blas. (2017) }\end{array}$ & Cambodia & $\begin{array}{l}\text { Quasi-experimental } \\
\text { Matching with non-participants }\end{array}$ & $\begin{array}{l}\text { Participants reported } \\
\text { more money related } \\
\text { reasons to protect forests } \\
\text { and were more likely to } \\
\text { rule breaking after } \\
\text { payments cease }\end{array}$ & No evidence \\
\hline $\begin{array}{l}\text { 5. Handberg and Angelsen } \\
\text { (2017) }\end{array}$ & Tanzania & $\begin{array}{c}\text { Experimental economics } \\
0 \%, 20 \%, 60 \% \text { and } 100 \% \text { PES in a public } \\
\text { goods game }\end{array}$ & No evidence & No evidence \\
\hline $\begin{array}{l}\text { 6. Kaczan, Swallow and } \\
\text { Adamowicz (2016) }\end{array}$ & Tanzania & $\begin{array}{l}\text { Experimental economics: Dictator game- } \\
\text { Individual vs. collective payment } \\
\text { low and high mandated levels of } \\
\text { contribution, backed by penalties }\end{array}$ & No evidence & No evidence \\
\hline $\begin{array}{l}\text { 7. Salk, López and Wong } \\
\text { (2017) }\end{array}$ & Lao PDR & $\begin{array}{l}\text { Experimental economics: Common pool } \\
\text { resources game } \\
\text { Individual, collective and insurance } \\
\text { payments }\end{array}$ & $\begin{array}{l}\text { No evidence after } \\
\text { incentive removal }\end{array}$ & $\begin{array}{l}\text { No evidence after incentive } \\
\text { removal }\end{array}$ \\
\hline
\end{tabular}




\section{Case study and methods}

\subsection{El Caraño in Caquetá}

This research was conducted in the corregimiento ${ }^{3}$ of El Caraño, municipality of Florencia, department of Caquetá, south-west Colombia (Figure 1). El Caraño sits within the Amazon Piedmont, an ecological transition zone characterized by high rates of biodiversity and deforestation and laying between the Andes and the tropical Amazon rainforest. Two of the main tributaries of the Amazon river, the Caquetá and the Putumayo rivers, start in the Amazon Piedmont.

Deforestation in Caquetá was the highest of Colombia in 2015, with 23.812 hectares lost (IDEAM, 2016) as a result of expanding agricultural and cattle rearing activities. 18.7\% of the remaining forests in El Caraño are highly vulnerable to deforestation because they can be easily reached by road, which facilitates the advancement of the agricultural frontier, and the development of illegal logging, mining exploration and charcoal making activities (Vélez et al., 2016). Not surprisingly then, several public, private, and multilateral conservation initiatives have targeted or plan to operate in Caquetá. The department is one of the selected strategic zones for piloting the 2017 National PES programme and it is one of the districts where the national NGO Patrimonio Natural (PN) plans to design and start the implementation of a PES scheme within the next few years. This research is part of a scoping study to support PN in the design of such PES scheme.

Our study involved participants from 13 rural districts in El Caraño, where land tenure is mostly informal: $65 \%$ of research participants do not hold any legal land title but claim possession of their farmed and forest plots. Plots are located either inside the National Forest Reserve of the Amazonia- public lands- or are legally owned by large private landholders. Settlements in the area are the product of violent conflict in other regions that forced families to re-locate. This settlement pattern is important because many of the inhabitants are officially considered colonos who cleared the forest to plant subsistence crops (Vázques- Delgado, 2015). The median farm size of the research participants is 15 hectares and approximately $5 \%$ of plot size is allocated to coffee cultivation, which is the main cash crop in Caquetá, alongside sugarcane (6.2\%) and profitable cattle rearing.

\footnotetext{
${ }^{3}$ A Colombian administrative unit that involves a specific number of rural districts.
} 
Figure 1: location of Río Hacha watershed.

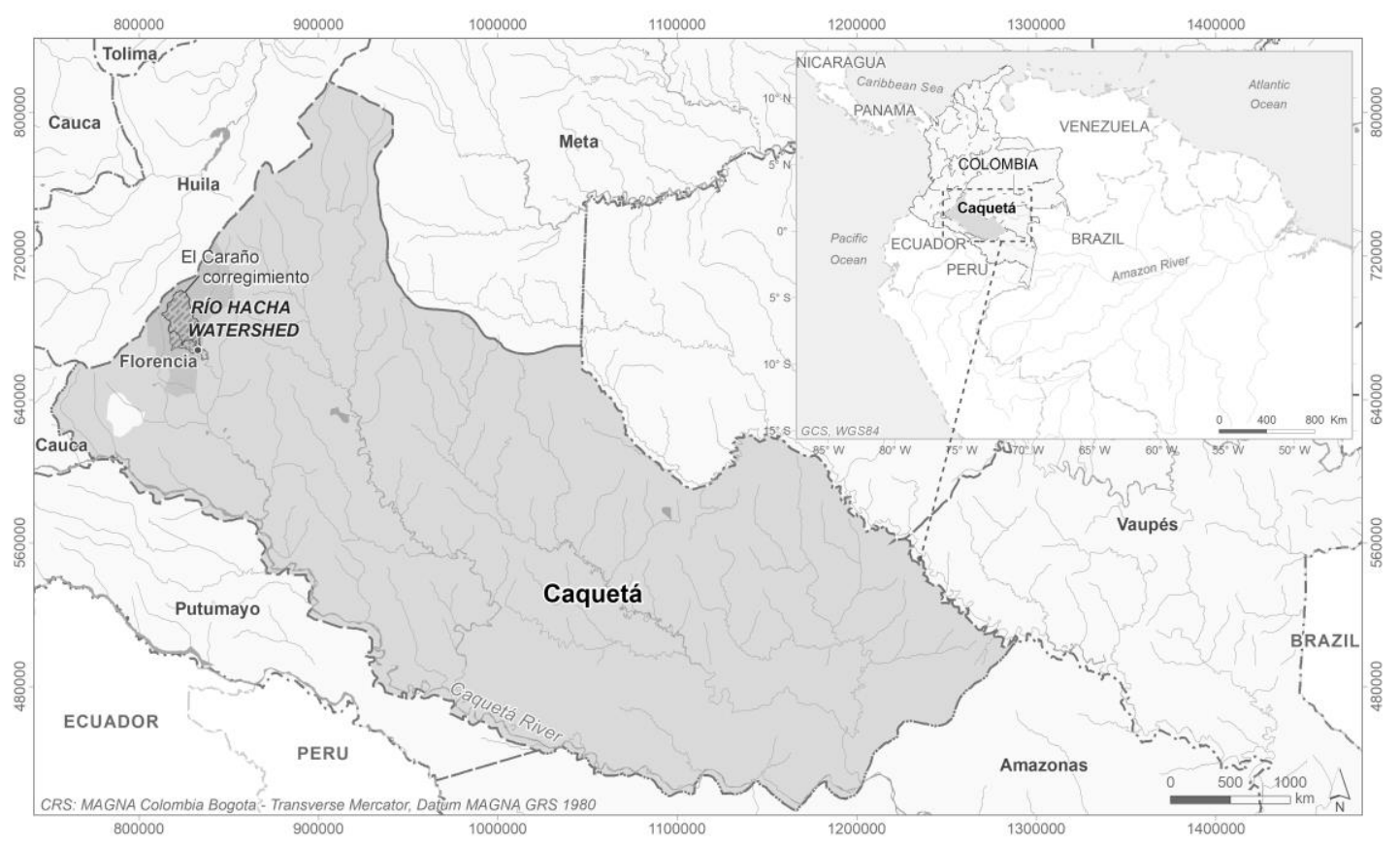

Source: cartographic data from Digital Chart of the World, GDAM, SO HYBAM and IGAC 2014.

Forests cover $50 \%$ of the research participants' plots on average, while the rest is allocated to farming and cattle. Material conditions vary greatly: some farmers have extremely precarious living conditions (e.g. very low income and no kitchen or toilet in their house) while others are above the municipality average condition (e.g. a wellequipped house and various productive assets). Average household size is 4 people and families arrived approximately 11 years ago to El Caraño, with some settiling more than 40 years ago and others only a few months before our study (Vélez et al., 2016).

\subsection{Methods}

To explore the effects of PES on farmers' motivations we relied on two research instruments: a framed field economic experiment and a post-experiment survey. We also conducted a preliminary fieldwork process that included a series of interviews $(n=7)$, workshops with community members $(n=52)$, and deploying a pilot questionnaire in seven rural districts of El Caraño to test the motivation survey and to gather key sociodemographic, productive and environmental knowledge data $(n=100)$. Between the $5^{\text {th }}$ and the $10^{\text {th }}$ of September 2016, 257 farmers participated in an experimental economics game and responded to a motivations-related survey after the experiment ${ }^{4}$.

Participants were randomly assigned to control and treatment groups. Participants in the control groups (CGs) participated in a game without any PES involved, and participants

\footnotetext{
${ }^{4}$ They were also invited to a socialization workshop to discuss research results in September $10^{\text {th }} 2016$, which was attended by 85 research participants.
} 
in the treatment groups (TGs) played a game with one out of four possible payment types. Our test of motivational crowding is based on the comparison of post-experiment survey responses between CGs and TGs following a between group design. Crowding-out is thus understood as any negative difference in the responses to the motivations survey between groups; crowding-in is, in contrast, understood as any positive difference in the motivations survey comparing control vs. treatment groups. Hence, any difference on motivations between groups (CGs vs TGs) can be attributed to participation in the experiment ${ }^{5}$.

As noted in the Introduction, we develop a post-experiment survey to compare participants' experimental behavior with their survey responses in order to grasp more accurately the extent to which payments crowd-in or crowd-out motivations to conserve the forest. Experimental behavior reveals participants' willingness to conserve in response to different incentives, but it does not say anything explicit about the kind of motivations that have driven such behavior. The latter can, however, be captured through the survey. An alternative research design would have been to conduct a survey on motivations before and after the experiment (within research design). Two main reasons refrained us to do so: first, it is very likely that asking participants to respond to a survey on forest protection before participating in the experiment would have influenced their behavior in the game towards more conservation behavior. Second, we wanted to avoid that participants sought for consistency in their responses before and after the experiment (Festinger, 1962). Thus, and given our between group design approach, the recruitment strategy was set in order to ensure that individuals were randomly assigned to sessions and groups.

Each participant received a written note including the date and hour of her/his session and slots were allocated randomly across villages and families. This random allocation to groups and sessions allowed us to control for observable and un-observable variables, such as pre-existent motivations to protect forests. Eleven game sessions were conducted in Spanish with the support of six research assistants. Each session implemented a different treatment. Farmers, both men and women older than 18 years, were invited both face-to-face by two research assistants and through a local leader. The sessions were implemented in a local school of a village that was conveniently located for ensuring participants' attendance. Each round of the experiments and the post-experiment survey were delivered in two sessions of 3 hours per day. Between 12 and 28 people participated in each session ${ }^{6}$. Before deploying the experiment and the survey, we introduced the project's aims to targeted participants and obtained their written consent, ensuring they

\footnotetext{
${ }^{5}$ We cannot rule out that CGs participants' motivations could have changed before and after the game. However, this possibility does not undermine our results. If CGs motivations are enhanced (or diminished) as a result of the baseline game, all our participants experienced the same baseline and the difference between them could only be related to the treatments. If anything, it would be harder for us to find significant differences between CGs and TGs, which is not the case.

6 Total number of participants in the experiment were 260. However, three participants left before conducting the survey and we have no socio-demographic data for them and are not included in our regression analysis.
} 
had understood that participation was voluntary and that they could leave at anytime (Annex 1).

\subsubsection{The economic experiment}

Our experiment is an adapted version of the public goods game with threshold by Narloch et al. 2012 and Midler et al. 2015 (hereafter Narloch and Midler). This experiment recreates a situation in which the environmental service is provided only if the group accomplishes a specific environmental objective (threshold). The threshold aims to recreate real-life situations in which the provision of an ecosystem service (water in our case) is conditional on collective performance (conservation of the forest). Also, the payment to farmers is granted only if the group complies with the threshold. This feature captures the objectives of the environmental organization operating in the area, which is interested in regional scale impacts rather than programs tailored at individual-farm performance. We extended Narloch and Midler design by implementing also a voting for the preferred payment and a payment in the form of a crop-price premium (Table 2). Our design also differs in its framing and number of rounds. While the mentioned articles frame the decision around traditional vs. commercial crop cultivation, our framing relates to forest conservation vs. crop cultivation. And while in Narloch and Midler the public benefits resulting from reaching the threshold are generic, ours refer specifically to the provision of water. In our design, the benefits of water provision (not quality or water improvement but quantity) are monetized. We conducted 10 rounds (and two additional ones for practice that are not analyzed), while Narloch and Milder implemented 12 rounds.

At the beginning of each session, the lead author of this paper read the instructions of the experiment following the conventional procedure for lab-in-the-field experiments. Posters with visuals were used to complement instructions and facilitate participants' comprehension of the experiment (Annex 2). After explaining the instructions, participants were randomly assigned to groups of 4 people by picking out a piece of paper marked with a letter and a number. Letters identified groups and numbers the participant within a given group.

In each round $(\mathrm{t})$, each participant $(i)$ received 4 units of land and had to privately decide how to use the land: to conserve forests (f) or plant crops $(c)$. For each land unit with forest cover $\left(x_{f}\right)$, each participant received $\$ 100$ pesos (USD 3 cents). For each unit of land with planted crops $\left(x_{C}\right)$, each participant received $\$ 600$ (USD 20 cents) ${ }^{7}$. If the group reached a threshold of units of forest, then a public good $\left(P G_{i}\right)$ in the form of water from the forest, and equivalent to $\$ 200$ pesos (USD 6 cents) for each unit of forest in the group, was provided to each participant regardless of his/her own level of forest conservation

\footnotetext{
${ }^{7}$ Payoffs were set to cover opportunity cost of participants based on daily wages in the zone which range between 20.000-40.000 pesos (6- 12 euros). Earnings in the experiment ranged from 24.000-54.000 (6-16 euros) for three hours of participation.
} 
contribution. Participants are informed about the threshold at the beginning of the experiment. In the experiment, economic returns from crops are higher than those from forest conservation to recreate the current situation in the region, where economic earnings from forests in the form of timber, firewood, medicines or food are lower than the market returns farmers can get from selling their agricultural harvest.

The experiment was structured around two stages: the baseline stage (rounds 1-5) and the payment stage (rounds 6-10). The difference between the two stages is that in the second stage a payment for conservation was introduced. Please note that CGs play all 10 rounds without receiving payments. We did not introduce a third stage removing the incentive (see Kaczan et al. 2016; Salk et al. 2016) because of methodological challenges related to the deployment of the post-experiment motivations survey. Table 2 describes the resulting numbers of participants according to different treatments.

Table 2. Number of participants and groups by treatment.

\begin{tabular}{|c|c|c|c|c|c|c|}
\hline \multirow{2}{*}{ Treatments } & \multirow{2}{*}{$\begin{array}{l}\text { Control } \\
\text { group }\end{array}$} & \multirow{2}{*}{$\begin{array}{l}\text { Individual } \\
\text { Payment }\end{array}$} & \multirow{2}{*}{$\begin{array}{l}\text { Collective } \\
\text { Payment }\end{array}$} & \multirow{2}{*}{$\begin{array}{l}\text { Crop-price } \\
\text { premium } \\
\text { payment }\end{array}$} & \multicolumn{2}{|c|}{ Voting } \\
\hline & & & & & $\begin{array}{l}\text { Individual by } \\
\text { voting }\end{array}$ & $\begin{array}{l}\text { Collective } \\
\text { by voting }\end{array}$ \\
\hline $\mathrm{N}=$ & 52 & 52 & 52 & 52 & 20 & 32 \\
\hline groups & 13 & 13 & 13 & 13 & 5 & 8 \\
\hline
\end{tabular}

\section{The baseline rounds}

During the baseline rounds, participants decided and marked their preferred combination supported by a "payoff table" (Annex 3). Subsequently, a researcher added up the total units of land covered by forests (the sum of the land units covered by forest from each of the 4 participants $\left(\sum X_{f}\right)$,), and she/he announced whether a threshold $(\theta)$ of 7 units had been reached. If so, and as noted earlier, a public good $\left(P G_{i}\right)$ in the form of water from the forest, and equivalent to $\$ 200$ pesos (USD 6 cents) for each unit of conserved forest in the group, was provided to each participant regardless of his/her own contribution to forest conservation. Therefore, as far as the minimum conservation threshold of 7 units was reached, this design allowed free-riding because participants who had not contributed to forest conservation could benefit from others' conservation efforts. Participants' earnings during the baseline rounds depended then on combining their private earnings from their own land-use choices - either forest or crops- $\left(x_{f i t}+x_{c i t}\right)$ and the aggregate conservation levels of their group which yielded collective earnings from water provision $\left(\sum X_{f}\right)$. Each participant $(i)$ had thus the following payoff function in the baseline stage:

$$
\pi_{i t}=\left\{\begin{array}{cc}
\$ 100 x_{\text {fit }}+\$ 600 x_{\text {cit }}+\$ 200\left(\sum X_{f}\right) & \text { if } \sum X_{f} \geq 7 \\
\$ 100 x_{\text {fit }}+\$ 600 x_{\text {cit }} & \text { if otherwise }
\end{array}\right.
$$


For example, if one participant allocated 2 units of land to crops and 2 to conserving forests his private earnings were $\$ 1.400(\$ 100 x 2+\$ 600 x 2)$. If, additionally, the group had managed to conserve a total of 7 forest units, the participant gained an additional sum of $\$ 200$ pesos for each unit of forest conserved by the group $(\$ 200 \times 7)$. Total earnings for this participant in this round were thus $\$ 2.800$ pesos (see Annex 3 for payoff table). Choosing forest instead of crops represented a direct cost to participants of $\$ 500$ pesos per unit of land (\$600-\$100) while the provision of the public good was uncertain since it depended on the decisions of other group members.

To understand players' best strategy during the baseline one needed to consider players' expectations about others' behavior. If player $(i)$ expected that the threshold was not going to be met, his best strategy was to allocate zero units of land to forest. If he expected the threshold to be reached, the best strategy was to allocate one or two units of lands to forest. The social optimum, ie. when the group's aggregate earnings are maximized, resulted from each farmer allocating four units of land to forest. However, the social optimum is never a Nash equilibrium because there are always incentives to defect (Annex 4).

\section{The payment rounds}

During the second stage (rounds 6-10) one of 4 different payments was implemented only if the community conserved a minimum of 7 units of forest. In other words, if the forest conservation threshold of 7 units was reached, each participant gained the $\$ 200$ pesos for the provision of water, plus an additional monetary payment recreating a payment for ecosystem services. Following Midler et al. (2015) we introduced both individual and collective payments because these are feasible payment alternatives for the environmental organization operating in the area.

Each farmer played one of the 4 different payments after playing the baseline. All four payments were framed as if a generic environmental organization (OA, organización ambiental in Spanish) aimed to pay for the protection of biodiversity and forest ecosystem services (e.g. climate regulation, soil protection and landslides prevention). The private payment for conserving the forests was $\$ 200$ pesos for each unit of forest conserved, and only if the group collectively reached the threshold of 7 units of forest conservation. This meant that each participant was paid the following amount, according to his/her own conservation effort:

$$
\pi_{i t}=\left\{\begin{array}{cr}
\$ 100 x_{f i t}+\$ 600 x_{c i t}+\$ 200\left(\sum X_{f}\right)+\$ 200 x_{f i t} \text { if } \sum X_{f} \geq 7 \\
\$ 100 x_{f i t}+\$ 600 x_{c i t} & \text { if otherwise }
\end{array}\right.
$$

The collective payment consisted of a payment of $\$ 50$ pesos per unit of land allocated to forest conservation by the group, and again only if the group had a minimum of 7 units 
of conserved forest. Unlike the private payment, in the collective payment each participant was rewarded according to the group collective conservation effort $\left(\sum X_{f}\right)$ :

$$
\pi_{i t}=\left\{\begin{array}{lr}
\$ 100 x_{\text {fit }}+\$ 600 x_{\text {cit }}+\$ 200\left(\sum X_{f}\right)+\$ 50\left(\sum f X_{f}\right) & \text { if } \sum X_{f} \geq 7 \\
\$ 100 x_{\text {fit }}+\$ 600 x_{\text {cit }} & \text { if otherwise }
\end{array}\right.
$$

The crop-price premium payment had not been included in Midler et al. 2015. Each participant received $\$ 150$ pesos for each unit of land allocated to crops only if the group allocated at least 7 units of land to forest. This payment aimed to recreate a situation in which efforts to preserve the forests were rewarded via a crop-price premium in agricultural products. Unlike the individual and collective payment, the crop-price premium condition explicitly considers that conservation and economic goals are not mutually exclusive, with the payoff function under this payment being as follows:

$$
\pi_{i t}=\left\{\begin{array}{cc}
\$ 100 x_{f i t}+\$ 600 x_{c i t}+\$ 200\left(\sum X_{f}\right)+\$ 150 x_{c i t} & \text { if } \sum X_{f} \geq 7 \\
\$ 100 x_{\text {fit }}+\$ 600 x_{\text {cit }} & \text { if otherwise }
\end{array}\right.
$$

Finally, in the voting payment, each person voted individually and privately before round 6 for their preferred payment between three options: no payment, individual or collective. The option with more votes was then implemented for the rest of the rounds. If there was a tie a coin was thrown. This feature was introduced to simulate a situation in which some level of agency, or participation in the design, is allowed. Voting on design features has been explored in common pool or public good studies with mixed results (Cherry \& Shogren, 2007; Vélez et al., 2012; Wahl et al., 2010; Walker et al., 2000).

Depending on the expectations of others and assuming that individuals are profit maximizers, all payments are expected to increase the units of land allocated to forest because they expand the set of best strategies compared to the baseline rounds. However, under the crop price premium incentives to defect are higher because a payment for ecosystem service is provided conditional on the accomplishment of the environmental threshold, but final earnings depend on the individual units of land allocated to crops. Nash equilibria and best strategies for collective and crop-price premium are the same, but different from private payment (following original design). Hence, our experimental analysis is conducted comparing baseline vs. payment rounds for each type of payment. We did not have a hypothesis of which payment would work better in terms of forest conservation, but based on Midler and Narloch findings, we expected that individual payments would increase forest conservation levels compared to the no-payment condition. Payments decided by voting were also expected to increase forest conservation because this mechanism would, in theory at least, enhance feelings of autonomy and competence. 


\subsubsection{The motivations survey}

We used the results of the pilot questionnaire as the basis for the design of the postexperiment survey. The pilot questionnaire was developed taking into account Ryan and Deci's SDT (2000) and Pelletier et al.'s MTES principles (1998) with six motivation categories. Each category included four statements or items, and participants were asked to respond from 1 to 4 if they agreed with the provided sentence. Items were anchored to deforestation because of its relevance to our study site: perception among inhabitants is that forest clearing is the main environmental problem they are actually facing (according to survey responses), and Caquetá is also the most deforested department in the country (IDEAM,2016).

A factor analysis of the pilot questionnaire results was conducted to determine the consistency of motivation categories and reduce the dimensionality of data. As a result, the final survey we employed after the economic experiment contained eight motivation items that had factor loadings ${ }^{8}$ above 0.55 as suggested by Hair et al. (2009) and that conceptually captured four types of motivations to protect the forests that vary on their degree of being internally or externally driven: intrinsic, guilt/regret, social, and extrinsic motivations (Table 3).

Purely intrinsic motivations are the most self-directed and do not require the support of external institutions or incentives to persist over time (Pelletier et al., 1998). In the context of our study, they relate to the inherent pleasure or joy that arises from protecting forests. According to SDT we can expect that feelings of autonomy or self-competence might trigger intrinsic motivations to protect forests.

Guilt/regret motivations are explained by one's desire of aligning with the values and beliefs held by a group of people, community or society, and they are related to ones' need of self-approval. The feeling of guilt/regret thus acts as an internal motivator to perform a particular task, but is externally influenced. In our study, these motivations refer to the feelings of guilt/regret that may arise as a result of deforesting, particularly when conservation is related to moral or ethical principles (Werff et al., 2013). According to SDT theory, guilt/regret could be triggered by moderators such as competence because individuals might feel frustrated/satisfied and their self-esteem or self-image might be reduced/enhanced.

Social motivations are related to the need of being accepted by others and maintaining certain social reputation, and they are thus also influenced by external institutions and customary practices. In our study, they refer to people's fear of being criticized by local peers and significant others that may promote socially and environmentally desirable behaviors (Kinzig et al., 2013). As for guilt/regret, the need to adhere to the social norm

\footnotetext{
${ }^{8}$ Factor analysis is a statistical method that describes the variability between observed and correlated variables in terms of a smaller number of unobserved variables, or factors.
} 
or maintain a certain reputation reflects the fact that social motivations are both internally and externally triggered. The moderator of social relatedness- or "the quality of one's relations with others" (Ezzine-de-Blas et al. in this issue) - is expected to activate social motivations through reinforcing or reducing image motivation.

Finally, purely extrinsic motivations are those explained by the existence of direct incentives (e.g. payments) or penalties (e.g. fines), which exert as direct behavioral drivers. In our study, these are represented by payments and fines designed to either encourage conservation or discourage deforestation (Table 3).

Table 3. Description of the survey motivation items, and the correspondent statements.

\begin{tabular}{|c|c|c|c|}
\hline Motivation & Description & SDT moderators & Survey statements \\
\hline Purely intrinsic & $\begin{array}{l}\text { Captures inherent } \\
\text { interest for forest } \\
\text { conservation as well as } \\
\text { self-endorsement of } \\
\text { forest protection }\end{array}$ & $\begin{array}{l}\text { Autonomy and } \\
\text { competence }\end{array}$ & $\begin{array}{l}\text { 1. "I enjoy when I do not } \\
\text { clear the forest" } \\
\text { 2. "I see myself as } \\
\text { someone who does not } \\
\text { clear the forests" }\end{array}$ \\
\hline Guilt or regret & $\begin{array}{l}\text { Captures motivations } \\
\text { related to need of self- } \\
\text { approval }\end{array}$ & Competence & $\begin{array}{l}1 \text { "I would feel guilty if I } \\
\text { clear the forests" } \\
\text { 2. "I would regret it if I } \\
\text { clear the forests" }\end{array}$ \\
\hline Social & $\begin{array}{l}\text { Includes motivations that } \\
\text { rise from the need of } \\
\text { social approval or } \\
\text { reputation }\end{array}$ & Social relatedness & $\begin{array}{l}\text { 1. "I would be criticized by } \\
\text { my neighbors if I clear the } \\
\text { forests" } \\
\text { 2. "Significant others } \\
\text { would be upset if I clear } \\
\text { the forests" }\end{array}$ \\
\hline $\begin{array}{l}\text { Purely extrinsic - } \\
\text { Incentives }\end{array}$ & $\begin{array}{l}\text { Captures motivations } \\
\text { that emerge exclusively } \\
\text { from external payments }\end{array}$ & $\begin{array}{l}\text { Combination of three } \\
\text { moderators }\end{array}$ & $\begin{array}{c}\text { "I would take care of } \\
\text { forests only if I am paid to } \\
\text { do so" }\end{array}$ \\
\hline $\begin{array}{l}\text { Purely extrinsic - } \\
\text { Penalties }\end{array}$ & $\begin{array}{c}\text { Captures motivations } \\
\text { that emerge from fear to } \\
\text { fines }\end{array}$ & $\begin{array}{l}\text { Combination of three } \\
\text { moderators }\end{array}$ & $\begin{array}{l}\text { "I do not cut down the } \\
\text { forests because of fear to } \\
\text { fines that might be } \\
\text { imposed by environmental } \\
\text { authorities" }\end{array}$ \\
\hline
\end{tabular}

Our final survey used a four-point Likert scale to capture variations in the motivations to protect forests. The scale was symmetric, ranging from 1 (totally disagree) to 4 (totally agree), and did not have a central point with the aim of forcing respondents to go in one direction or another and eliminate the risk of neutral responses (Lozano et al., 2008). Socio-demographic information on gender, income, education level and economic activities as well as information related to forest management was also collected. The post-experiment survey took between 20-40 minutes and we used an open access mobile application (KOBO) to input responses offline and make data cleaning and analysis more efficient afterwards (Annex 1). Visual supporting material was also used to help participants note if they agreed with the sentence. 


\section{Results}

\subsection{Checking for randomization among groups}

To compare survey responses between groups we needed first to establish if CGs and TGs were indeed comparable. We conducted t-tests for participants' age and monthly income, and chi-squared tests on proportion of men and women, and on levels of education. We found no statistically significant differences between CGs and TGs on observable socio-demographic characteristics (see Annex 5 for sample details). There were some differences across treatments and we controlled for them in the regression analysis, but note that our main reference for comparison is CGs vs TGs.

We also conducted a regression analysis of allocations of forest in round 1 and in round 5 using a Tobit model ${ }^{9}$. Analysis of round 1 allowed us to capture initial levels of conservation and to determine whether groups started off with similar levels and thus were comparable. Analysis of round 5 allowed us to establish the dynamics in baseline stage across treatments and to check for particular trends that might affect our results. Conservation levels in round 1 were higher for participants in the individual payment treatment compared to the CGs and lower for the individual payment by voting compared to the CGs. In round 5 these initial differences disappeared for the individual payment treatment but remained for the individual payment by voting. In the behavioral analysis (see below), we used a difference-in-difference model (DiD) to control for such differences.

\subsection{Motivations under different types of payments - survey results}

Although our research design implemented the economic experiment first, followed by the motivations survey, we present below the survey results followed by the experimental results for analytic and argumentative purposes.

\subsubsection{Descriptive statistics}

We created an index of intrinsic, guilt/regret and social motivations as the average of the two items in each category ${ }^{10}$. For fines and payments, we did not build an index because there is only one item for each category. Figure 2 presents mean values for each type of motivation across treatments. Motivations range from 1 to 4 and higher values means more motivation of a specific type.

\footnotetext{
${ }^{9}$ Regression is not included but available upon request.

${ }^{10}$ Correlation coefficient between the two intrinsic items is 0.2539 ; between the two guilt/regret items is 0.3837 and for the social items is 0.5429 . All correlation coefficients are statistically significant at 1 . Correlation coefficient between intrinsic and payment type of motivations is negative (as expected because they measure conceptually opposite types of motivations) and statistically significant at $1 \%$.
} 
Figure 2. Mean values for different types of motivations. Asterisks mean statistically significant differences between CGs and each TGs using a Kruskal-Wallis test (*** $\mathrm{p}<0.01, * * \mathrm{p}<0.05, * \mathrm{p}<0.1)$.

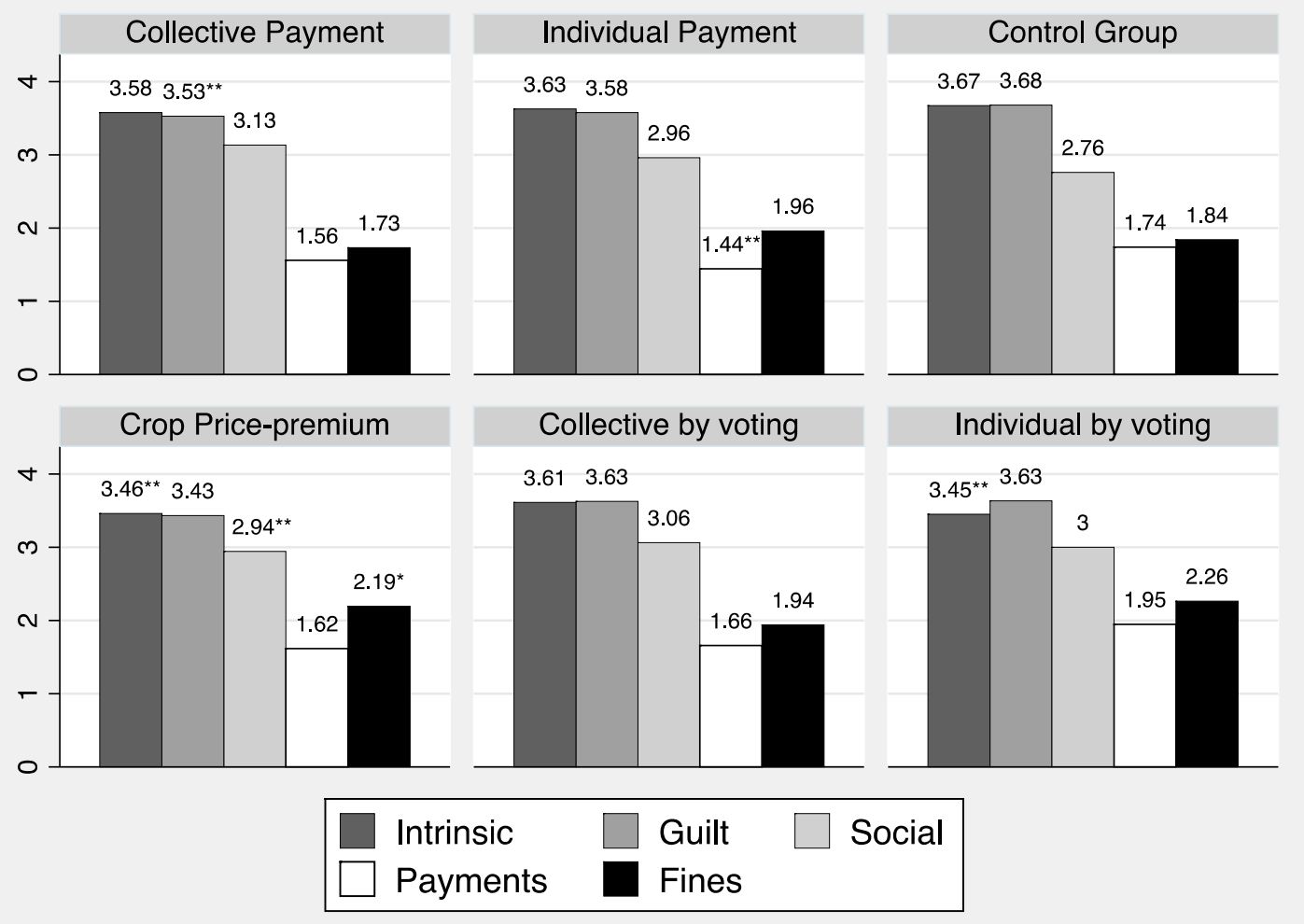

Figure 2 shows that higher values were reported for intrinsic and guilt/regret related motivations to protect forests across treatments. Social motivations appeared less important, and expectations of payments and fines did not seem very relevant. Histograms of each type of motivation per treatment show that the distribution of motivations is not symmetric (Annex 6). We also compared the motivations of the CGs ${ }^{11}$ and treatment groups using a Kruskal-Wallis test, which compares the medians of an ordinal variable between two or more groups when data distribution are not symmetric. In doing so, we found statistically significant differences between CGs and TGs.

For example, we found that intrinsic motivations were lower for the crop-price premium group ( $\mathrm{p}$-value $<0.05$ ) and the individual payment by voting group ( $\mathrm{p}$-value $<0.05$ ) compared to the CGs. We also found that social motivations were higher for the group that received the collective payment ( $\mathrm{p}$-value<0.05) compared to the CGs. Guilt/regret related motivations were lower for the group that received the crop-price premium payment ( $\mathrm{p}$-value<0.01) compared to the CGs, while extrinsic motivations related to payments were higher for the group that received the individual payment ( $\mathrm{p}$-value $<0.05$ )

\footnotetext{
${ }^{11}$ We also conducted Kruskal-Wallis test comparing motivations across treatments and found statistically significant differences at $10 \%$ in intrinsic, guilt and fines motivations between collective payment and crop Premium Price; differences at $10 \%$ in intrinsic motivations between individual payment and crop Premium Price; and differences at $10 \%$ in guilt motivations between crop premium price and collective payment by voting.
} 
compared to the CGs. Finally, we also found that extrinsic motivations related to fines were higher for the group that received a crop-price premium payment $(p$-value $<0.1$ ) compared to the CGs.

After this analysis, we conducted an ordered logistic regression for each type of motivation and controlled for socio-demographic variables and self-reported deforestation, as well as we included a dummy for each different type of payment to capture the effect of the treatment compared to the motivations in the CGs. Our dependent variables, each type of motivation, takes values from 1 to 4 . The five resulting regressions for each motivation category are presented in Table 4 (see Annex 7 for models with different specifications to test for consistency in our results). Coefficients represent the expected increase in the probabilities of the dependent variable due to an increase in the independent variable.

\subsubsection{Not all types of payments crowd out motivations}

Table 4 column (1) shows that crop-price premium payment has a negative effect on intrinsic motivations to protect forests (significant at 5\%). Being able to vote on the type of payment has also a negative effect on intrinsic motivations. These results suggest a crowding-out effect of the crop-price premium payment and the individual payment by voting on intrinsic motivations to protect forests. Note, however, that for the case of the voting treatment, we need to be cautious on claiming causality since, as explained in the following section, these are self-selected groups by definition. Voting treatment is assigned randomly across groups, but the decision on the type of payment is not. Therefore, group behavior in the first stage of the game might influence the voting decision.

Regarding the effect of demographics on intrinsic motivations, no difference is observed comparing men and women, or comparing by age groups. However, a higher level of education has a positive effect on intrinsic motivations to protect forests. If the participant reported to have cut down the forest or sold timber in the past, intrinsic motivations to protect forests are more likely to decrease compared to a participant who has never deforested or sold timber.

Column (2) shows that guilt/regret related motivations to protect forests are crowded out when an incentive in the form of crop-price premium is introduced compared to the CGs controlling for the correspondent socio-demographics. Contrary to intrinsic or social motivations (read below), guilt/regret motivations seem to be explained only by age, where older participants are more likely to report higher motivations related to guilt or regret compared to younger ones.

Column (3) suggests that participating in a collective payment (either pre-defined or selected by voting) vs CGs increases the likelihood of being sensitive to social motivations to protect forests. Note again that in the case of voting treatment we need to 
recall the self-selection nature of these groups and thus be cautious in interpreting these results. However, this result suggests a crowding-in effect of collective payments on social motivations to protect the forests. Socio-demographic factors explain to a small extent the participants' social motivations to protect forests: it is observed that older participants are more likely to report more social motivations to protect the forests than younger ones.

Finally, Table 4 also shows that responses to "I take care of the forests only if I'm paid to do so" (column 4) and "I do not cut down the forests because of fear to fines that might be imposed by environmental" (column 5) are not affected by the type of payment in the experiment (no significant differences). Men were more likely to report external payments or fines as the only reason to protect forests compared to women, and some level of education (e.g. primary school not finished) and higher levels of formal education decreases the probability of reporting payments as the only reason to protect forests, compared to participants without formal education. Older and more educated participants were less likely to report fines as a reason for forest protection compared to younger and not educated participants.

Table 4. Ordered logit regression for each type of motivation controlling for sociodemographic variables.

\begin{tabular}{|c|c|c|c|c|c|}
\hline Variables & $\begin{array}{c}\text { (1) } \\
\text { Intrinsic }\end{array}$ & $\begin{array}{c}\text { (2) } \\
\text { Guilt/Regret }\end{array}$ & $\begin{array}{c}(3) \\
\text { Social }\end{array}$ & $\begin{array}{c}\text { (4) } \\
\text { Payments }\end{array}$ & $\begin{array}{c}(\mathbf{5}) \\
\text { Fines }\end{array}$ \\
\hline \multirow{2}{*}{ Individual payment } & -0.576 & -0.424 & 0.602 & -0.668 & 0.319 \\
\hline & $(0.427)$ & $(0.393)$ & $(0.371)$ & $(0.442)$ & $(0.424)$ \\
\hline \multirow[t]{2}{*}{ Collective payment } & -0.372 & -0.377 & $1.021 * * *$ & -0.349 & -0.0720 \\
\hline & $(0.445)$ & $(0.413)$ & $(0.376)$ & $(0.427)$ & $(0.436)$ \\
\hline \multirow{2}{*}{$\begin{array}{l}\text { Crop-price premium } \\
\text { payment }\end{array}$} & $-0.999 * *$ & $-1.019 * * *$ & 0.558 & -0.253 & 0.492 \\
\hline & $(0.412)$ & $(0.383)$ & $(0.362)$ & $(0.404)$ & $(0.406)$ \\
\hline \multirow[t]{2}{*}{ Individual by voting } & $-1.229 * *$ & -0.299 & 0.328 & 0.400 & 0.848 \\
\hline & $(0.531)$ & $(0.527)$ & $(0.468)$ & $(0.580)$ & $(0.557)$ \\
\hline \multirow[t]{2}{*}{ Collective by voting } & -0.500 & -0.341 & $0.757 *$ & -0.106 & 0.151 \\
\hline & $(0.474)$ & $(0.459)$ & $(0.418)$ & $(0.490)$ & $(0.493)$ \\
\hline \multirow[t]{2}{*}{ Sex } & -0.251 & 0.0229 & -0.273 & $0.699 * *$ & $0.612 * *$ \\
\hline & $(0.264)$ & $(0.249)$ & $(0.233)$ & $(0.286)$ & $(0.271)$ \\
\hline \multirow[t]{2}{*}{ Age } & 0.00823 & $0.0231 * *$ & $\begin{array}{c}0.0276 * * \\
*\end{array}$ & -0.00645 & $-0.0241 * *$ \\
\hline & $(0.00982)$ & $(0.00949)$ & $(0.00877)$ & $(0.0109)$ & $(0.0101)$ \\
\hline \multirow{2}{*}{$\begin{array}{l}\text { Primary school } \\
\text { incomplete }\end{array}$} & 0.668 & -0.260 & 0.162 & $-1.236 * *$ & $-1.331 * * *$ \\
\hline & $(0.466)$ & $(0.475)$ & $(0.422)$ & $(0.497)$ & $(0.459)$ \\
\hline \multirow[t]{2}{*}{ Primary school complete } & 0.305 & -0.307 & 0.306 & -0.508 & $-1.155^{* * *}$ \\
\hline & $(0.412)$ & $(0.442)$ & $(0.380)$ & $(0.420)$ & $(0.420)$ \\
\hline \multirow[t]{2}{*}{ High school not finished } & 0.696 & -0.476 & 0.444 & $-0.971^{*}$ & $-2.488 * * *$ \\
\hline & $(0.541)$ & $(0.556)$ & $(0.481)$ & $(0.571)$ & $(0.581)$ \\
\hline \multirow[t]{2}{*}{ High school finished } & -0.00837 & -0.221 & -0.267 & $-1.764 * * *$ & $-2.311 * * *$ \\
\hline & $(0.500)$ & $(0.522)$ & $(0.464)$ & $(0.606)$ & $(0.549)$ \\
\hline
\end{tabular}




\begin{tabular}{|l|c|c|c|c|c|}
\hline $\begin{array}{l}\text { More than high school } \\
\text { (university, graduate) }\end{array}$ & $\mathbf{1 . 4 8 2} * *$ & -0.0199 & 0.292 & $\mathbf{- 2 . 0 7 9} * * *$ & $-2.570 * * *$ \\
\cline { 2 - 6 } & $(0.587)$ & $(0.550)$ & $(0.492)$ & $(0.691)$ & $(0.647)$ \\
\hline \multirow{3}{*}{ Has cut down the forest? } & $\mathbf{- 1 . 2 3 0} * * *$ & $\mathbf{- 0 . 5 0 1 *}$ & -0.399 & 0.239 & 0.242 \\
\cline { 2 - 6 } & $(0.277)$ & $(0.272)$ & $(0.252)$ & $(0.298)$ & $(0.284)$ \\
\hline \multirow{2}{*}{$\begin{array}{l}\text { Want children to become } \\
\text { farmers? }\end{array}$} & 0.261 & 0.144 & $\mathbf{- 0 . 5 9 5} * *$ & -0.0429 & 0.418 \\
\cline { 2 - 6 } & $(0.290)$ & $(0.281)$ & $(0.268)$ & $(0.323)$ & $(0.310)$ \\
\hline Observations & 257 & 257 & 257 & 257 & 257 \\
\hline
\end{tabular}

\subsection{Behavior under different types of payments - experimental results}

Figure 3 describes the average units of land allocated to forest and the success rate by payment, comparing stage 1 with stage 2 . This comparison reflects conservation levels within groups and it allows us to infer if the payment was effective under a particular type of payment. Conservation levels are high enough across treatments in stage 1 (from 1.82 to 2.42/4) and the success rate, calculated as the percentage of rounds in which the total forest in the community is greater than 7 units, is very high for all treatments except for individual payment by voting (56\%). In the first 5 rounds of the CGs, for example, $90 \%$ of the rounds were observed to meet the threshold. This behavior might reflect the effect that the threshold has on cooperation for conservation as it provides a clear sign of the desired behavior and a focal point for coordination. This puts additional challenges for payments effectiveness because participants are already conserving forests without any external financial incentive (see Annex 8 for success rates across treatments).

For CGs, Figure 3 shows that without any payment to protect forests units of land allocated to forest decrease from stage 1 (2.35) to stage 2 (2.19). This difference is not statistically significant but gives a first insight of what we can expect when running regressions that control for observables. For TGs, we observe a general increase in forest units except for crop-price premium. There are statistically significant differences for crop-price premium payment ( $\mathrm{p}$-value $<0.1$ ), collective payment by voting ( $\mathrm{p}$-value $<0.05$ ) and individual payment by voting ( $\mathrm{p}$-value $<0.01$ ). However, in the first stage, there are differences in the average forest units conserved between individuals who voted for individual payment and those who voted for collective payment: the former showed a lower average of forest units than the rest, which suggest that they might have been influenced by group dynamics during the first stage of the game ${ }^{12}$.

\footnotetext{
${ }^{12}$ Of the 13 groups that played under the voting treatment, in 4 groups there was a tie between the options and it was necessary to throw the coin to decide which treatment was played in the following 5 rounds. However, whether the payment was by majority or random does not seem to affect overall results. Of the 13 groups that played under the voting treatment, in 8 won the collective payment and in 5 the individual payment. In the groups in which it won the collective payment, the voting was of 3: 1 in all groups except for one group in which there was tie and the coin was thrown. In the 5 groups in which it won the individual payment, in three groups a coin was thrown and in 2 the individual payment won by 3 votes vs. 1
} 
Figure 3. Average units of forest by type of payment and per stage. Asterisks denote differences comparing stage 1 and stage 2 conservation levels per treatment ( $* * * p<0.01$, ** $\mathrm{p}<0.05, * \mathrm{p}<0.1)$.

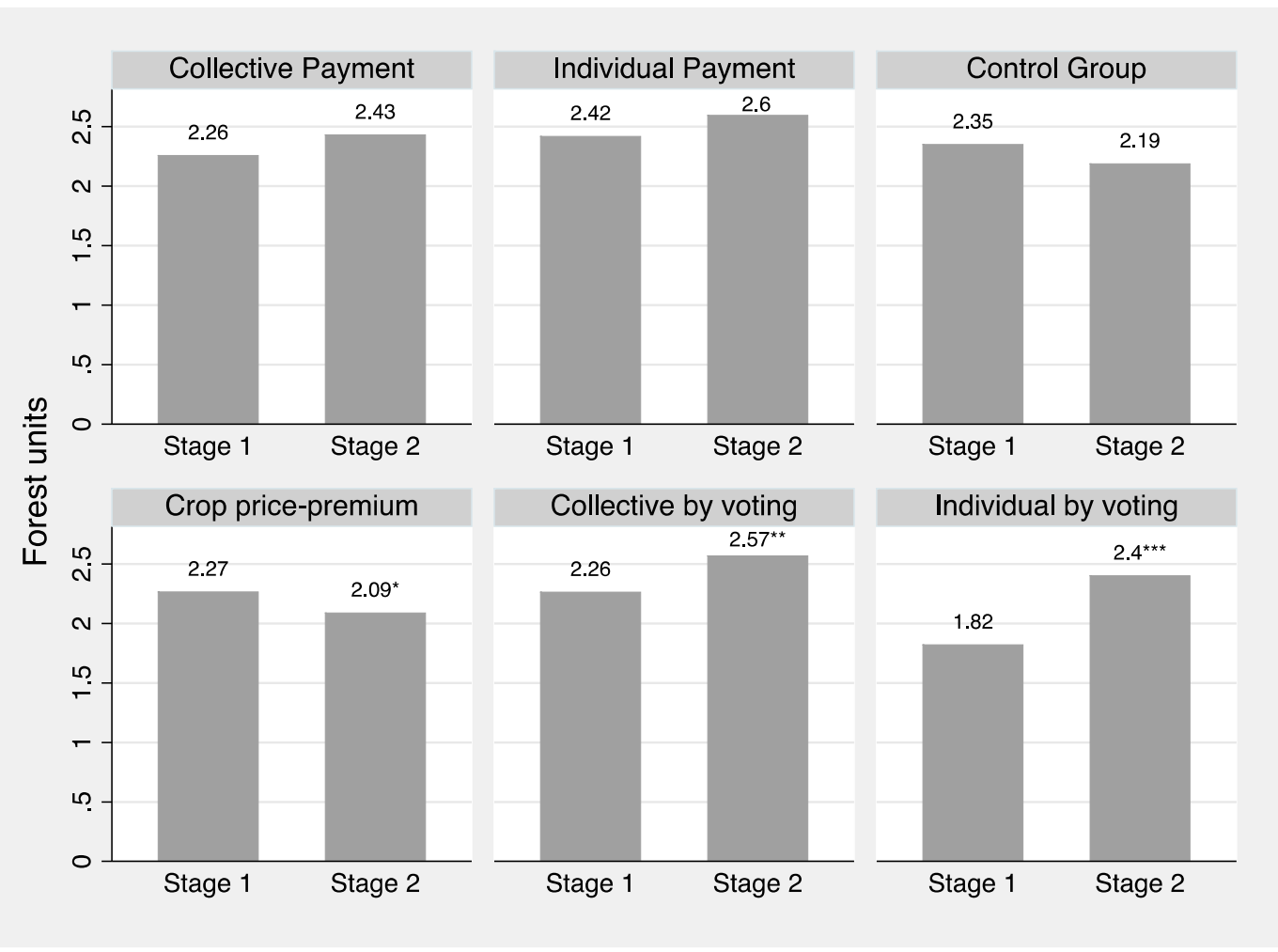

Taking advantage of the panel structure of our data, we conducted an individual-level analysis over time. Recall each individual made decisions over 10 rounds. Thus, we had 2570 observations in total. In Table 5 we take the units of land in forest cover as our dependent variable and conduct a random effects Tobit model considering participant repeated information. We followed the DiD framework, hence we created a payment dummy variable for each type of payment (treatment) that takes values of " 1 " if the participant was assigned to the treatment and " 0 " otherwise. We also included a dummy variable for stage of the game which takes values of " 0 " for rounds 1-5 and "1" for rounds 6-10. We interacted payment dummy with stage dummy in order to determine the differential effect of the second stage on each type of payment. We also included as independent variables the total units of forest in previous rounds to capture the dynamics and learning through the experiment, and socio-demographic information ${ }^{13}$.

\footnotetext{
${ }^{13}$ We also conducted additional regression analyses following a random effects Tobit model and an OLS model with dummy variables for different types of payment including a dummy for the control group, a dummy for number of round to capture trends that might be affecting the behaviour in the game and sociodemographic information. Results drawn from this analysis confirm our findings using the DiD framework and are available upon request.
} 
Table 5. Random effects Tobit analysis for units of land covered by forest using the DiD framework.

\begin{tabular}{|l|c|c|}
\hline Variables & $\begin{array}{c}\text { Units of land covered by } \\
\text { forest }\end{array}$ & $\begin{array}{c}\text { Standard } \\
\text { errors }\end{array}$ \\
\hline Individual payment (rounds 1 to 5) & -0.0476 & $(0.270)$ \\
\hline Collective payment (rounds 1 to 5) & -0.0625 & $(0.272)$ \\
\hline Individual payment by voting (rounds 1 to 5) & $-0.767^{* *}$ & $(0.366)$ \\
\hline Collective payment by voting (rounds 1 to 5) & -0.202 & $(0.311)$ \\
\hline Crop-price Premium payment (rounds 1 to 5) & 0.00201 & $(0.268)$ \\
\hline Stage & -0.148 & $(0.128)$ \\
\hline Individual_payment* Stage & $0.520^{* * *}$ & $(0.182)$ \\
\hline Collective_payment*Stage & $0.480^{* * *}$ & $(0.183)$ \\
\hline Individual_payment_voting*Stage & $1.123^{* * *}$ & $(0.251)$ \\
\hline Collective_payment_voting*Stage & $0.658^{* * *}$ & $(0.210)$ \\
\hline Crop- Price_premium*Stage & -0.168 & $(0.180)$ \\
\hline Total of forest in previous round & $0.0408^{* * *}$ & $(0.0147)$ \\
\hline Sex & -0.138 & $(0.160)$ \\
\hline Age & 0.00399 & $(0.00598)$ \\
\hline Primary school incomplete & 0.220 & $(0.265)$ \\
\hline Primary school complete & $0.516^{*}$ & $(0.292)$ \\
\hline Highschool not finished & 0.137 & $(0.337)$ \\
\hline Highschool finished & 0.163 & $(0.325)$ \\
\hline More than highschool (university, graduate) & -0.328 & $(0.339)$ \\
\hline Has cut down the forest? & 0.107 & $(0.174)$ \\
\hline Want children to become farmers? & 0.0166 & $(0.182)$ \\
\hline Constant (Control rounds 1 to 5) & $1.750^{* * *}$ & $(0.220)$ \\
\hline Observations & 2,313 & \\
\hline Number of id & 257 & \\
\hline & &
\end{tabular}

$* * * \mathrm{p}<0.01, * * \mathrm{p}<0.05, * \mathrm{p}<0.1$

Table 5 shows that the coefficient for all types of payments in rounds 1 to 5 , except for the individual payment by voting are, as expected, not statistically significant compared to the CGs in rounds 1 to 5. This means that treatment groups are comparable and no particular group characteristics are affecting conservation levels. However, as noted, participants on the "individual payment by voting" group display less environmental preferences compared to the CGs. Although we acknowledge that individual payment and collective payment by voting are self-selected groups, we report results separately for the two groups because these differences are still informative. Coefficient for variable stage, capturing rounds 6-10 for the CGs, is negative but not statistically significant.

As for the interactions, capturing the effect of rounds 6-10 for each type of payment, all (except for crop price-premium) are positive and statistically significant at $1 \%$. This means that all types of payments increase forest conservation levels when the payment is introduced (round 6-10). The interaction term is not significant for the crop pricepremium, suggesting that there are no differences in conservation levels comparing stage 
" 0 " and stage " 1 " of the game for this group. Although comparing treatments directly is not entirely correct due to the self-selection bias of the voting treatment, we conducted a post estimation test to compare coefficients. We observe that individual payment by voting is the most effective compared to individual ( $\mathrm{p}$-value $<0.05$ ), collective payments ( $\mathrm{p}$-value $<0.01)$ and collective by voting ( $\mathrm{p}$-value $<0.1)$. No other differences are observed. However, these results should be taken with caution because, as mentioned earlier, individuals who voted for the individual payment were choosing more crops than forest in the first stage compared to other treatment groups.

\section{Discussion and conclusion}

This paper set out to investigate the relationship between motivational crowding, types of motivations, and the specific features of a simulated PES scheme to be implemented in the study area. In doing so, we implemented a framed field experiment and a postexperiment motivations survey, involving 257 rural dwellers of the Colombian Amazon Piedmont. In summary, our findings show that all types of PES, except for the crop-price premium payment, increased conservation behavior in the experiment; but not all types of payments affected motivations equally: collective payments enhanced social motivations to protect forests, the crop-price premium reduced intrinsic and guilt/regret related motivations, while voting reduced intrinsic motivations for the case of individual payment and enhanced social motivations for those who voted for the collective type of payment (Table 6).

Table 6: Summary of findings analyzing motivations and behaviors separately.

\begin{tabular}{|c|c|c|}
\hline Treatment & $\begin{array}{c}\text { Motivations to } \\
\text { protect forests }\end{array}$ & $\begin{array}{c}\text { Forest conservation } \\
\text { Behavior }\end{array}$ \\
\hline Individual payment & n/e & Increases \\
\hline Collective payment & $\begin{array}{c}\text { Crowd in } \\
\text { social motivations }\end{array}$ & Increases \\
\hline Premium price payment & $\begin{array}{c}\text { Crowd out } \\
\text { intrinsic and guilt/regret } \\
\text { motivations }\end{array}$ & Increases \\
\hline Collective by Voting & $\begin{array}{c}\text { Crowd in } \\
\text { social motivations } \\
\text { Individual by voting }\end{array}$ & $\begin{array}{c}\text { Crowd out } \\
\text { intrinsic motivations }\end{array}$ \\
\hline
\end{tabular}

The fact that collective payments fostered social motivations to protect forests might be because participants probably perceived such payments as a means to promote a cooperative culture (Gagné \& Forest, 2008), which led them to consider others' opinions regarding forest conservation more centrally in their individual reasoning. Collective payments might have activated the psychological mechanism of social belongingness and connectedness to a group (social relatedness). Consequently, we expected that the 
possibility of voting would have increased participants' sense of autonomy for those voting for collective payments and thus would have translated into higher social motivations to conserve, particularly compared to those who received a collective payment but did not have a choice. However, we found that both the pre-defined and voted collective payment crowded-in social motivations.

When discussing with participants their preferred type of payment after the experiment and the survey were conducted, no consensus was reached and more disadvantages than opportunities were mentioned for the collective payment compared to the individual. Community leaders thought collective payments could help coordinating proenvironmental collective action across the district, while other community members preferred individual payments, as the latter depended on "one's responsibility" and reflected "one's willingness to care about the forest". Our results on collective payments are consistent with findings of motivational crowding-in when collective benefits are realized (Agrawal et al., 2015) but contradict those of Narloch et al. (2012) and Midler et al. (2015), who found that collective payments crowd-out social norms for conservation. This contradicting result might be explained by the social and institutional context where the experiment was implemented, or by the fact that Narloch and Midler measure motivational crowding through an experiment alone.

Another finding of our research is that individual payments selected by voting reduced intrinsic motivations to protect forests, which consistently align with those who argue that individual payments, regardless of whether they have been selected or not over other payment options, are likely to erode intrinsic motivations and reinforce extrinsic ones (Chervier et al., 2017; Frey, 1994). This result, however, should be treated with caution since some form of reverse causality may have been operating when conducting the voting: choosing the individual payment was probably the result of participants' low level of intrinsic environmental motivations and not vice versa.

Finally, crop-price premium payments reduced intrinsic and guilt/regret related motivations, probably because this type of payment conveyed a message that released participants from a moral responsibility to conserve forests and, simultaneously, reinforced positive attitudes about crop production. This type of payment is different from individual and collective PES because it pays for allocating land to crops and not to forest conservation. Hence, while the "desired behavior" in the context of paying for forest conservation was clear, the crop-price payment made such desirable behavior less evident. In a participant's own words, "under this type of payment, it is easy to forget the initial environmental objective [of the payment]". Also, it is no surprise that our results showed no effect of the crop-price premium on social motivations because the cooperative framework mentioned above is not activated under this treatment.

In conclusion, how do our results inform the future implementation of PES in El Caraño and beyond? In contrast with other studies (Midler et al., 2015; Narloch et al., 2012), we think that collective PES can reinforce social motivations and potentially result in 
increased forest protection. From the implementer's perspective, such payments are suitable when transaction costs of individual payments are high and/or local collective action is strong and involves high levels of trust and equitable benefit sharing (Engel, 2016). In whichever form, and given that PES are far from "neutral" policy tools, their design and implementation should be carefully crafted, taking into account and adapting over time to existing social-ecological and development pathways, institutional settings, cross-scale power dynamics, and participants' preferences, among others (BerbésBlázquez et al., 2016; Rodriguez-de-Francisco \& Budds, 2015; Van Hecken et al., 2015).

This article has hopefully also illuminated new areas of enquiry. For example, more research is needed to understand how participatory mechanisms -such as voting for the type of preferred incentive- affects pro-environmental motivations in experimental and real implementation settings. Replicating our methodological approach across distinct tenure regimes and social organization settings could help exploring if such regimes affect experimental behavior and individual motivations. We could expect that social motivations to protect forest are more important in contexts of strong community organization than in context of individual land ownership, as observed in many ethnic territories around the world (Ostrom, 1999; Ostrom, 2000).

Investigating the effects of cancelling payments on individuals' motivations and conservation behavior is of theoretical and practical relevance. Policies and programs are not commonly funded in perpetuity, and they suffer budgetary and implementation adjustments along the way. It would also desirable to develop more research to understand how pro-environmental motivations affect real life decisions on forest conservation. Quantitatively, this would require including a measure of motivations as an explanatory variable of real conservation behavior using, for example, historical satellite images of forest cover at farm-level. Additionally, future experimental research would benefit from considering the role of self-reported motivations on observed environmental behaviors. All these research endeavors together would expand our understanding of the relation between PES, motivations and observed behaviors in environmental conservation.

\section{Acknowledgments}

The authors thank Alexander Pfaff, Luz Angela Rodríguez, Carlos Trujillo, Ximena Rueda, Jeroen van den Bergh and two anonymous reviewers for their comments and suggestions to earlier versions of this manuscript. We also thank the research assistants who supported the implementation of the experiments: Santiago Caicedo, Juliana Unda, Liliana Guerrero, Yady Barrera, Camilo Acosta, Camilo Perdomo, and particularly Juan Sebastián Rodríguez who coordinated field logistics and participants' recruitment. Arutza Rico provided excellent support designing the game graphics and Marta Borrós at ICTA-UAB in elaborating the study site map. Special thanks to the inhabitants of the rural districts of El Caraño for their hospitality and willingness to participate in the study. The research fieldwork was carried out under the contract CYG-G-087, subscribed between "Patrimonio Natural Fondo para la Biodiversidad y Áreas Protegidas" and "Universidad de los Andes" in the context of the "Conservación y Gobernanza" program financially supported by USAID. EC thanks the financial support 
of the UAB-Banco de Santander Talent Retention Programme and notes that this work contributes to ICTA-UAB "María de Maeztu Unit of Excellence” (MDM-2015-0552). The article's contents are the authors' own responsibility and do not necessarily reflect the views of Patrimonio Natural, USAID or the United States Government.

\section{References}

Agrawal, A. (2005). Environmentality. Technologies of Government and the Making of Subjects. Duke University Press.

Agrawal, A., Chhatre, A., \& Gerber, E. R. (2015). Motivational Crowding in Sustainable Development Interventions. American Political Science Review, 109(3), 470-487. https://doi.org/10.1017/S0003055415000209

Alix-Garcia, J., Sims, K. R., Yanez-Pagans, P., \& Shapiro, E. N. (2015). Only One Tree from Each Seed? Environmental Effectiveness and Poverty Alleviation in Programs of Payments fro Ecosystem Services. American Economic Journal: Economic Policy, 7(4), 56. https://doi.org/10.1257/pol.20130139

Ariely, D., Bracha, A., \& Meier, S. (2009). Doing Good or Doing Well?: Image Motivation adn Monetary Incentives in Behaving Proscially. American Economic Review, 99, 544-555. https://doi.org/10.1257/aer.99.1.544

Arriagada, R., Ferraro, P., Sills, E., Pattanayak, S., Cordero-Sancho, S. (2012) Do Payments for Environmental Services Affect Forest Cover? A Farm-Level Evaluation from Costa Rica. Land Economics 88 (2), 382-399. doi:10.3368/le.88.2.382

Asquith, N. M., Vargas, M. T., \& Wunder, S. (2008). Selling two environmental services: In-kind payments for bird habitat and watershed protection in Los Negros, Bolivia. Ecological Economics, 65(4), 675-684. https://doi.org/10.1016/j.ecolecon.2007.12.014

Bandura, A. (1977). Self-efficacy: Toward a unifying theory of behavioral change. Psychological Review, 84, 191-215.

Berbés-Blázquez, M., González, J. A., \& Pascual, U. (2016). Towards an ecosystem services approach that addresses social power relations. Current Opinion in Environmental Sustainability, 19, 134-143. https://doi.org/10.1016/j.cosust.2016.02.003

Börner, J., Baylis, K., Corbera, E., Ezzine-de-Blas, D., Honey-Rosés, J., Persson, U. M., $\&$ Wunder, S. (2017). The Effectiveness of Payments for Environmental Services. World Development, 96, 359-374. https://doi.org/10.1016/j.worlddev.2017.03.020

Bowles, S., \& Polanía-Reyes, S. (2012). Economic Incentives and Social Preferences : Substitutes or Complements? Journal of Economic Literature, 50(2), 368-425.

Bremer, L. L., Farley, K. A., \& Lopez-Carr, D. (2014). What factors influence participation in payment for ecosystem services programs? An evaluation of Ecuador's SocioPáramo program. Land Use Policy, 36, 122-133. https://doi.org/10.1016/j.landusepol.2013.08.002

Calvet-Mir, L., Corbera, E., Martin, A., Fisher, J., \& Gross-Camp, N. (2015). Payments for ecosystem services in the tropics: a closer look at effectiveness and equity.

Current Opinion in Environmental Sustainability, 14(May), 150-162. https://doi.org/10.1016/j.cosust.2015.06.001

Cherry, T. L., \& Shogren, J. F. (2007). Rationality crossovers. Journal of Economic Psychology, 28(2), 261-277. https://doi.org/10.1016/j.joep.2006.12.002

Chervier, C., Le Velly, G., \& Ezzine-de-Blas, D. (2017). When the Implementation of 
Payments for Biodiversity Conservation Leads to Motivation Crowding-out : A Case Study From the Cardamoms. Ecological Economics.

https://doi.org/10.1016/j.ecolecon.2017.03.018

De Groot, J. I. M., \& Steg, L. (2008). Value Orientations to explain beliefs related to environmental significant behavior. Environment and Behavior, 40(3), 330-354.

De Groot, J. I. M., \& Steg, L. (2010). Relationships between value orientations, selfdetermined motivational types and pro-environmental behavioural intentions.

Journal of Environmental Psychology, 30(4), 368-378. https://doi.org/10.1016/j.jenvp.2010.04.002

Deci, E., Koestner, R., \& Ryan, R. (1999). A meta-analytic review of experiments examining the effects of extrinsic rewards on intrinsic motivation. Psychological Bulletin, 125(6), 627-668.

Dedeurwaerdere, T., Admiraal, J., Beringer, A., Bonaiuto, F., Cicero, L., FernandezWulff, P., Hagens, J., Hiedanpaa, J., Knights, P., Molinario, E., Melindi-Ghidi, P., Popa, F., Silc, U.,Soethe, N., Soininen, T.,Vivero, J.,(2016). Combining internal and external motivations in multi-actor governance arrangements for biodiversity and ecosystem services. Environmental Science and Policy, 58 (January ), 1-10. https://doi.org/10.1016/j.envsci.2015.12.003

Dolan, P., Hallsworth, M., Halpern, D., King, D., \& Vlaev, I. (2011). Mindspace: Influencing behaviour through public policy. London.

Dunlap, R. E., Liere, K. D. Van, Mertig, A. G., \& Jones, R. E. (2000). Measuring Endorsement of the New Ecological Paradigm : A Revised NEP Scale. Journal of Social Issues, 56(3), 425-442. https://doi.org/10.1111/0022-4537.00176

Engel, S. (2016). "The devil in the detail: A practical guide on designing payments for environmental services. "International Review of Environmental and Resource Economics forthcoming.

Engel, S., Pagiola, S., \& Wunder, S. (2008). Designing payments for environmental services in theory and practice: An overview of the issues. Ecological Economics, 65(4), 663-674. https://doi.org/10.1016/j.ecolecon.2008.03.011

Ezzine-de-Blas, D., Corbera, E., \& Lapeyre, R. (2017). Crowding-in or crowding-out? A conceptual framework to understand motivations in payments for ecosystem services. Ecological Economics forthcoming.

Festinger, L. (1962). A theory of cognitive dissonance. Standford University Press.

Frey, B.(1994). How intrinsic motivation is crowded out and in. Rationality and Society 6, 334-352.

Fisher, J. (2012). No pay, no care? A case study exploring motivations for participation in payments for ecosystem services in Uganda. Oryx, 46(1), 45-54. https://doi.org/10.1017/S0030605311001384

Frey, B. (1994). How intrinsic motivation is crowded out and in. Rationality and Society, 6, 334-352.

Gagné, M., \& Forest, J. (2008). The study of compensation systems through the lens of self-determination theory: Reconciling 35 years of debate. Canadian Psychology/Psychologie Canadienne, 49(3), 225-232. https://doi.org/10.1037/a0012757

Gneezy, U., Meier, S., \& Rey-Biel, P. (2011). When and Why Incentives (Don't) Work to Modify Behavior. Journal of Economic Perspectives, 25(4), 191-210. https://doi.org/10.1257/jep.25.4.191

Gneezy, U., \& Rustichini, A. (2000). Pay Enough or Don' t Pay at.The Quarterly Journal of Economics, 115(3), 791-810.

Gómez-Baggethun, E., de Groot, R., Lomas, P. L., \& Montes, C. (2010). The history of 
ecosystem services in economic theory and practice: From early notions to markets and payment schemes. Ecological Economics, 69(6), 1209-1218.

https://doi.org/10.1016/j.ecolecon.2009.11.007

Greiner, R. (2015). Motivations and attitudes influence farmers' willingness to participate in biodiversity conservation contracts. Agricultural Systems, 137, 154165. https://doi.org/10.1016/j.agsy.2015.04.005

Greiner, R., Patterson, L., \& Miller, O. (2009). Motivations, risk perceptions and adoption of conservation practices by farmers. Agricultural Systems, 99(2-3), 86104. https://doi.org/10.1016/j.agsy.2008.10.003

Grillos, T. (2017). Economic vs non-material incentives for participation in an in-kind payments for ecosystem services program in Bolivia. Ecological Economics, 131, 178-190. https://doi.org/10.1016/j.ecolecon.2016.08.010

Grima, N., Singh, S. J., Smetschka, B., \& Ringhofer, L. (2016). Payments for Ecosystem Services (PES) in Latin America: Analysing the performance of 40 case studies. Ecosystem Services, 17, 24-32. https://doi.org/10.1016/j.ecoser.2015.11.010

Hair, J., Black, W., Babin, B., \& Anderson, R. (2009). Multivariate data analysis (7th Edition). Harlow: UK: Pearson New International Edition.

Handberg, Ø. N., \& Angelsen, A. (2016). Pay little, get little; pay more, get a little more: a framed field experiment in Tanzania. Ecological Economics forthcoming.

Hendrickson, C. Y., \& Corbera, E. (2015). Participation dynamics and institutional change in the Scolel Té carbon forestry project, Chiapas, Mexico. Geoforum, 59, 63-72. https://doi.org/10.1016/j.geoforum.2014.11.022

Herzberg, F. (1965). The motivation to Work Among Finnish Supervisors. Personnel Psychology, 18(4), 393-402. https://doi.org/10.1111/j.1744-6570.1965.tb00294.x

IDEAM. (2016). La cifra de deforestación en Colombia 2015 reporta 124.035 hectáreas afectadas. Retrieved from http://www.ideam.gov.co/web/sala-de-prensa/noticias//asset_publisher/96oXgZAhHrhJ/content/la-cifra-de-deforestacion-en-colombia2015-reporta-124-035-hectareasafectada?_101_INSTANCE_96oXgZAhHrhJ_redirect=http\%3A\%2F\%2Fwww.ide am.gov.co\%2Fweb\%2Fsala-de-pren

Kaczan, D. J., Swallow, B. M., \& Adamowicz, W. L. V. (2016). Forest conservation policy and motivational crowding: Experimental evidence from Tanzania. Ecological Economics forthcoming. https://doi.org/10.1016/j.ecolecon.2016.07.002

Kahneman, D., Knetsch, J. L., Thaler, R., \& Kahneman, B. D. (2011). Fairness as a Constraint on Profit Seeking : Entitlements in the Market. The American Economic Review. 76(4), 728-741.

Kinzig, A.P., Ehrlich, P.R., Alston, L.J., Arrow, K., Barrett, S., Buchman, T.G., Daily, G.C., Levin, B., Levin, S., Oppenheimer, M., Ostrom, E., Saari, D. (2013) Social Norms and Global Environmental Challenges: The Complex Interaction of Behaviors, Values, and Policy. Bioscience 63 (3), 164-175. doi:10.1525/bio.2013.63.3.5

Kosoy, N., \& Corbera, E. (2010). Payments for ecosystem services as commodity fetishism. Ecological Economics, 69(6), 1228-1236. https://doi.org/10.1016/j.ecolecon.2009.11.002

Kosoy, N., Corbera, E., \& Brown, K. (2008). Participation in payments for ecosystem services: Case studies from the Lacandon rainforest, Mexico. Geoforum, 39(6), 2073-2083. https://doi.org/10.1016/j.geoforum.2008.08.007

Lastra-Bravo, X. B., Hubbard, C., Garrod, G., \& Tolón-Becerra, A. (2015). What drives farmers' participation in EU agri-environmental schemes?: Results from a 
qualitative meta-analysis. Environmental Science \& Policy, 54, 1-9.

https://doi.org/10.1016/j.envsci.2015.06.002

Le Grand, J. (2006). Motivation, Agency, and Public Policy of Knights and Knaves,

Pawns and Queens. Oxford: Oxford University Press.

Lindenberg, S., \& Steg, L. (2007). Normative, Gain and Hedonic Goal Frames Guiding Environmental Behavior, 63(1), 117-137.

Lozano, L. M., García-Cueto, E., \& Muñiz, J. (2008). Effect of the Number of Response Categories on the Reliability and Validity of Rating Scales. Methodology, 4(2), 73-79. https://doi.org/10.1027/1614-2241.4.2.73

Midler, E., Pascual, U., Drucker, A. G., Narloch, U., \& Soto, J. L. (2015). Unraveling the effects of payments for ecosystem services on motivations for collective action. Ecological Economics, 120, 394-405. https://doi.org/10.1016/j.ecolecon.2015.04.006

Moller, A.C., Ryan, R.M., Deci, E.L., (2006). Self-Determination Theory and Public Policy : Without Using Coercion. American Marketing Association, 25 (1), 104116.

Muradian, R., Arsel, M., Pellegrini, L., Adaman, F., Aguilar, B., Agarwal, B., Corbera, E., Ezzine-de-Blas, D., Farley, J., Froger, G., García-Frapolli, E., GómezBaggethun, E., Gowdy, J., Kosoy, N., Le Coq, J.F., Leroy, P., May, P., Méral, P., Mibielli, P., Norgaard, R., Ozkaynak, B., Pascual, U., Pengue, W., Perez, M., Pesche, D., Pirard, R., Ramos-Martin, J., Rival, L., Saenz, F., Van Hecken, G., Vatn, A., Vira, B., Urama, K. (2013). Payments for ecosystem services and the fatal attraction of win-win solutions. Conservation Letters, 6 (4), 274-279. doi:10.1111/j.1755-263X.2012.00309.x

Narloch, U., Pascual, U., \& Drucker, A. G. (2012). Collective Action Dynamics under External Rewards: Experimental Insights from Andean Farming Communities. World Development, 40(10), 2096-2107. https://doi.org/10.1016/j.worlddev.2012.03.014

Ostrom, E.(1999) Revisiting the Commons: Local Lessons, Global Challenges. Science 284, 278-282. doi:10.1126/science.284.5412.278

Ostrom, E. (2000) Social capital : a fad or a fundamental concept ?, in: Dasgupta, P., Serageldin, I. (Eds.), Social Capital: A Multifaceted Perspective. World Bank Publications, Washington, pp. 172-214.

Pagiola, S., Arcenas, A., \& Platais, G. (2005). Can Payments for Environmental Services Help Reduce Poverty? An Exploration of the Issues and the Evidence to Date from Latin America. World Development, 33(2), 237-253. https://doi.org/10.1016/j.worlddev.2004.07.011

Pascual, U., Muradian, R., Rodríguez, L. C., \& Duraiappah, A. (2010). Exploring the links between equity and efficiency in payments for environmental services: A conceptual approach. Ecological Economics, 69(6), 1237-1244. https://doi.org/10.1016/j.ecolecon.2009.11.004

Pelletier, L. G., Tuson, K. M., Green-Demers, I., Noels, K., \& Beaton, A. M. (1998). Why Are You Doing Things for the Environment? The Motivation Toward the Environment Scale (MTES). Journal of Applied Social Psychology, 28(5), 437468. https://doi.org/10.1111/j.1559-1816.1998.tb01714.x

Rico García-Amado, L., Ruiz Pérez, M., \& Barrasa García, S. (2013). Motivation for conservation: Assessing integrated conservation and development projects and payments for environmental services in la sepultura biosphere reserve, mexico, chiapas. Ecological Economics, 89, 92-100. https://doi.org/10.1016/j.ecolecon.2013.02.002 
Rode, J., Gómez-Baggethun, E., \& Krause, T. (2015). Motivation crowding by economic incentives in conservation policy: A review of the empirical evidence. Ecological Economics, 117, 270-282. https://doi.org/10.1016/j.ecolecon.2014.11.019

Rodríguez de Francisco, J. C., Budds, J., \& Boelens, R. (2013). Payments for Environmental Services and Unequal Resource Control in Pimampiro, Ecuador. Society \& Natural Resources, 26(10), 1217-1233. https://doi.org/10.1080/08941920.2013.825037

Ruiz-mallén, I., Schunko, C., Corbera, E., Rös, M., \& Reyes-garcía, V. (2015). Meanings, drivers, and motivations for community-based conservation in. Ecology and Society, 20(3). https://doi.org/10.5751/ES-07733-200333

Ryan, R., \& Deci, E. (1985). Intrinsic motivation and self-determination in human behavior. New York: Plenum.

Ryan, R., \& Deci, E. (2000). Intrinsic and Extrinsic Motivations: Classic Definitions and New Directions. Contemporary Educational Psychology, 25(1), 54-67. https://doi.org/10.1006/ceps.1999.1020

Ryan, R. L., Erickson, D. L., \& De Young, R. (2003). Farmers' motivations for adopting conservation practices along Riparian zones in a mid-western agricultural watershed. Journal of Environmental Management, 46(1), 19-37.

Salk, C., Lopez, M. C., \& Wong, G. (2016). Simple Incentives and Group Dependence for Successful Payments for Ecosystem Services Programs: Evidence from an Experimental Game in Rural Lao PDR. Conservation Letters, 1-8. https://doi.org/10.1111/conl.12277

Schlüter, M., Baeza, A., Dressler, G., Frank, K., Groeneveld, J., Jager, W., Janssen, M.A., Mcallister, R.R.J., Müller, B., Orach, K., Schwarz, N., Wijermans, N.(2017) A framework for mapping and comparing behavioural theories in models of socialecological systems. Ecological Economics 131, 21-35. doi:10.1016/j.ecolecon.2016.08.008

Schultz, P. W. (2000). New Environmental Theories : Empathizing With Nature: The Effects of Perspective Taking on Concern for Environmental Issues. Journal of Social Issues, 56(3), 391-406. https://doi.org/10.1111/0022-4537.00174

Sommerville, M., Jones, J. P. G., Rahajaharison, M., \& Milner-Gulland, E. J. (2010). The role of fairness and benefit distribution in community-based Payment for Environmental Services interventions: A case study from Menabe, Madagascar. Ecological Economics, 69(6), 1262-1271. https://doi.org/10.1016/j.ecolecon.2009.11.005

Souto, T., Deichmann, J. L., Nunez, C., \& Alonso, A. (2014). Classifying conservation targets based on the origin of motivation: Implications over the success of community-based conservation projects. Biodiversity and Conservation, 23(5), 1331-1337. https://doi.org/10.1007/s10531-014-0659-9

Steg, L., (2016) Values, Norms , and Intrinsic Motivation to Act Proenvironmentally. Annual Review of Environmental Resources 41, 277-292. doi:10.1146/annurevenviron-110615-085947

Steg, L., Bolderdijk, J. W., Keizer, K., \& Perlaviciute, G. (2014). An Integrated Framework for Encouraging Pro-environmental Behaviour: The role of values, situational factors and goals. Journal of Environmental Psychology, 38, 104-115. https://doi.org/10.1016/j.jenvp.2014.01.002

Steg, L., \& Vlek, C. (2009). Encouraging pro-environmental behaviour : An integrative review and research agenda. Journal of Environmental Psychology, 29(3), 309317. https://doi.org/10.1016/j.jenvp.2008.10.004 
Thaler, R. H., \& Sunstein, C. R. (2008). Nudge: Improving decisions about health, wealth, and happiness. New Heaven: Yale University Press.

Titmuss, R. (1970). The Gift Relationship: From Human Blood to Social Policy. London: Allen and Unwin.

Van Hecken, G., Bastiaensen, J., \& Windey, C. (2015). Towards a power-sensitive and socially-informed analysis of payments for ecosystem services (PES): Addressing the gaps in the current debate. Ecological Economics, 120, 117-125. https://doi.org/10.1016/j.ecolecon.2015.10.012

Vatn, a. (2010). An institutional analysis of payments for environmental services. Ecological Economics, 69(6), 1245-1252. https://doi.org/10.1016/j.ecolecon.2009.11.018

Vázques- Delgado, T. (2015). Territorios, conflictos armado y política en el Caquetá: 1900 - 2010 (1st edition). Universidad de Los Andes, Colombia.

Vélez, M. A., Rueda, X., Moros, L., Link, A., Guerrero, A., \& Rodríguez, J. S. (2016). Paisajes productivos sostenibles: Diseño de un sistema de incentivos para la conservación en el piedemonte Amazónico. Bogotá, Colombia.

Vélez, M. A., Stranlund, J. K., \& Murphy, J. J. (2012). Preferences for government enforcement of a common pool harvest quota: Theory and experimental evidence from fishing communities in Colombia. Ecological Economics, 77, 185-192. https://doi.org/10.1016/j.ecolecon.2012.02.030

Vollan, B. (2008). Socio-ecological explanations for crowding-out effects from economic field experiments in southern Africa. Ecological Economics, 67(4), 560573. https://doi.org/10.1016/j.ecolecon.2008.01.015

Vroom, V. (1964). Work and motivation. New York: Wiley.

Wahl, I., Muehlbacher, S., \& Kirchler, E. (2010). The Impact of Voting on Tax Payments. Kyklos, 63(1), 144-158. https://doi.org/10.1111/j.14676435.2010.00464.x

Walker, J. M., Gardner, R., Herr, A., \& Ostrom, E. (2000). Collective Choice in the Commons: Experimental Results on Proposed Allocation Rules and Votes. The Economic Journal, 110(460), 212-234. https://doi.org/10.1111/1468-0297.00497

Werff, E. Van Der, Steg, L., \& Keizer, K. (2013). The value of environmental selfidentity: The relationship between biospheric values, environmental self-identity and environmental preferences, intentions and behaviour. Journal of Environmental Psychology, 34, 55-63. https://doi.org/10.1016/j.jenvp.2012.12.006

Wunder, S. (2013). When payments for environmental services will work for conservation. Conservation Letters, 6(4), 230-237. https://doi.org/10.1111/conl.12034

Young, R. De. (1986). Encouraging Environmentally Appropriate Behavior: The Role of Intrinsic Motivation. Journal of Environmental Systems. https://doi.org/10.2190/3FWV-4WM0-R6MC-2URB 
Annex 1. KOBO Links to the survey in English and Spanish and Informed Consent

English: https://ee.kobotoolbox.org/x/\#YMcY

Spanish: https://ee.kobotoolbox.org/x/\#YyW1

INFORMED VERBAL CONSENT (translation from Spanish)

Good morning:

We want to thank you for your participation today. The following activity is a different way of participating in a research project to understand how people make decisions.

You have been invited today because we are interested in understanding the opinions on the conservation of natural resources and productive practices in the Corregimiento of El Caraño. This activity is part of the project "Conservación y Gobernanza en el piedemonte Amazónico" implemented by Patrimonio Natural, a Colombian environmental organization, in alliance with the Gobernación del Caquetá.

First I will explain the purpose of this activity and give you detailed information so that you can decide whether you want to participate or not. I ask you to please keep quiet while explaining as this helps everyone to listen better. After I explain, you can ask questions by raising your hand.

The objective of this activity is to understand how people decide to use their land. This activity may be different from others in which you have participated in the past because in this activity you will earn money for every decision you make. You should be wondering why do we do this activity with cash? We use cash because we want to recreate real-life situations in which the decisions you make have an economic cost for you.

We have already done this activity with farmers in other parts of Colombia: in the Pacific, Antioquia, Huila, Cundinamarca, among others, in order to understand what motivates people to do what they do. Funds to finance this activity today come from International Cooperation.

Your earnings depend on the decisions you make and the decisions made by the other members of your group. The earnings of this activity are between $\$ 10,000$ and $\$ 70,000$ and the activity will last 3 hours.

First of all, it should be made clear that this is neither a government project nor a training workshop. It is a research project where we are studying how people make decisions about land use. In this way, we'll learn from your decisions and you will have participated in an activity that we hope you find useful and entertaining.

Your answers will be anonymous and no one will know what decisions you made, or how much you earned. Only the researchers will know. This activity does not imply any risk to you and you can leave at any time without any justification. However, if you withdraw before finishing the activity, we can not pay you what you have earned.

During the activity we will ask you to follow established rules such as not talking to others when not allowed and filling some formats. When the activity is finished we will ask you to answer a short survey about your productive practices. We will give a snack and in the end each participant will receive their earnings in cash.

Are there any questions up to here? If you have questions, raise your hand. If you have additional questions about this project, you can find detailed information on the sheet that we are giving you.

Please take the time to read the information sheet. If you can not read or did not bring your glasses one of us will help you. [Give time for them to read]

Are we ready to start? If you want to participate please raise your hand. 
Annex 2: Visual material used in the experiment.

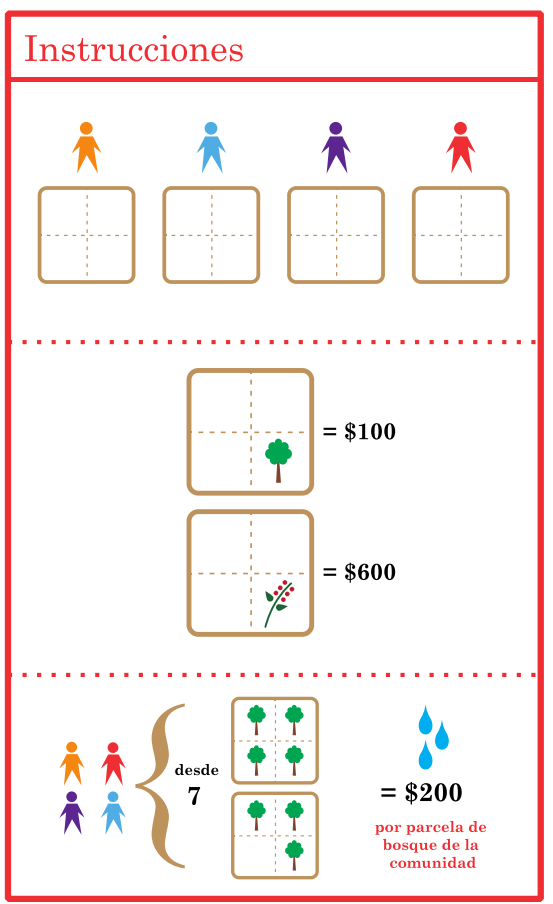


Annex 3. Pay off tables.

Individual payment

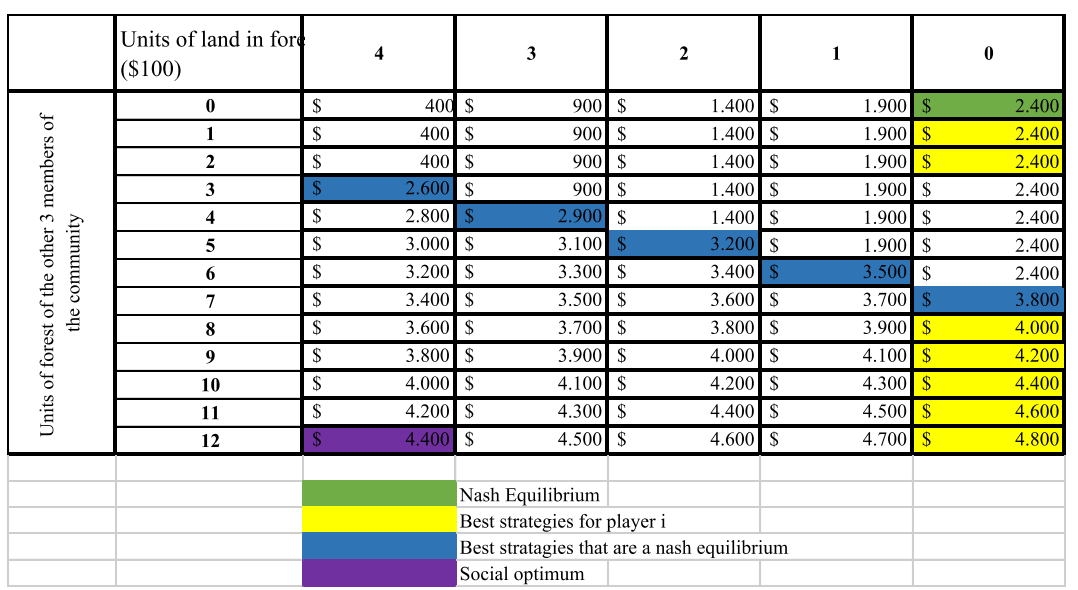

Collective payment

\begin{tabular}{|c|c|c|c|c|c|c|c|c|c|c|c|}
\hline & $\begin{array}{l}\text { Units of land in } \\
\text { forest }(\$ 100)\end{array}$ & & 4 & & 3 & & 2 & & 1 & & 0 \\
\hline \multirow{13}{*}{ 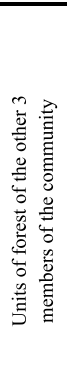 } & 0 & $\$$ & 400 & S & 900 & $\$$ & 1.400 & $\$$ & 1.900 & S & 2.400 \\
\hline & 1 & $\$$ & 400 & $s$ & 900 & $\$$ & 1.400 & $\$$ & 1.900 & $\$$ & 2.400 \\
\hline & 2 & $\$$ & 400 & s & 900 & $\$$ & 1.400 & $\$$ & 1.900 & $\$$ & 2.400 \\
\hline & 3 & $\$$ & 2.150 & s & 900 & $\$$ & 1.400 & $\$$ & 1.900 & $\$$ & 2.400 \\
\hline & 4 & $\$$ & 2.400 & s & 2.650 & $\$$ & 1.400 & $\$$ & 1.900 & $\$$ & 2.400 \\
\hline & 5 & $\$$ & 2.650 & $s$ & 2.900 & $\$$ & 3.150 & $\$$ & 1.900 & $\$$ & 2.400 \\
\hline & 6 & $\$$ & 2.900 & $s$ & 3.150 & $\$$ & 3.400 & $\$$ & 3.650 & $\$$ & 2.400 \\
\hline & 7 & $\$$ & 3.150 & $\$$ & 3.400 & $\$$ & 3.650 & $\$$ & 3.900 & $\$$ & 4.150 \\
\hline & 8 & $\$$ & 3.400 & $S$ & 3.650 & $\$$ & 3.900 & $\$$ & 4.150 & $\$$ & 4.400 \\
\hline & 9 & $\$$ & 3.650 & $\$$ & 3.900 & $\$$ & 4.150 & $\$$ & 4.400 & $\$$ & 4.650 \\
\hline & 10 & $\$$ & 3.900 & $S$ & 4.150 & $\$$ & 4.400 & $\$$ & 4.650 & $\$$ & 4.900 \\
\hline & 11 & $\$$ & 4.150 & $\$$ & 4.400 & $\$$ & 4.650 & $\$$ & 4.900 & $\$$ & 5.150 \\
\hline & 12 & $\$$ & 4.400 & $s$ & 4.650 & $\$$ & 4.900 & $\$$ & 5.150 & $\$$ & 5.400 \\
\hline
\end{tabular}

Crop-price premium payment

\begin{tabular}{|c|c|c|c|c|c|c|c|c|c|c|c|}
\hline & \begin{tabular}{|l}
$\begin{array}{l}\text { Units of land in } \\
\text { forest }(\$ 100)\end{array}$ \\
\end{tabular} & & 4 & & 3 & & 2 & & 1 & & 0 \\
\hline \multirow{13}{*}{ 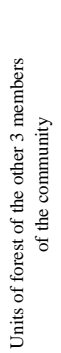 } & 0 & $\$$ & 400 & $\$$ & 900 & $\$$ & 1.400 & $\$$ & 1.900 & $\$$ & 2.400 \\
\hline & 1 & $\$$ & 400 & $\$$ & 900 & $\$$ & 1.400 & $\$$ & 1.900 & $\$$ & 2.400 \\
\hline & 2 & $\$$ & 400 & $\$$ & 900 & $\$$ & 1.400 & $\$$ & 1.900 & $\$$ & 2.400 \\
\hline & 3 & $\$$ & 1.800 & $\$$ & 900 & $\$$ & 1.400 & $\$$ & 1.900 & $\$$ & 2.400 \\
\hline & 4 & $\$$ & 2.000 & $\$$ & 2.450 & $\$$ & 1.400 & $\$$ & 1.900 & $\$$ & 2.400 \\
\hline & 5 & $\$$ & 2.200 & $\$$ & 2.650 & $\$$ & 3.100 & $\$$ & 1.900 & $\$$ & 2.400 \\
\hline & 6 & $\$$ & 2.400 & $\$$ & 2.850 & $\$$ & 3.300 & $\$$ & 3.750 & $\$$ & 2.400 \\
\hline & 7 & $\$$ & 2.600 & $\$$ & 3.050 & $\$$ & 3.500 & $\$$ & 3.950 & $\$$ & 4.400 \\
\hline & 8 & $\$$ & 2.800 & $\$$ & 3.250 & $\$$ & 3.700 & $\$$ & 4.150 & $\$$ & 4.600 \\
\hline & 9 & $\$$ & 3.000 & $\$$ & 3.450 & $\$$ & 3.900 & $\$$ & 4.350 & $\$$ & 4.800 \\
\hline & 10 & $\$$ & 3.200 & $\$$ & 3.650 & $\$$ & 4.100 & $\$$ & 4.550 & $\$$ & 5.000 \\
\hline & 11 & $\$$ & 3.400 & $\$$ & 3.850 & $\$$ & 4.300 & $\$$ & 4.750 & $\overline{\$}$ & 5.200 \\
\hline & 12 & $\$$ & 3.600 & $\$$ & 4.050 & $\$$ & 4.500 & $\$$ & 4.950 & $\$$ & 5.400 \\
\hline
\end{tabular}


Annex 4. Set of best private strategies of forest conservation and nash equilibria by payment.

\begin{tabular}{|l|c|l|l|c|}
\hline & Base-line & $\begin{array}{l}\text { Individual } \\
\text { payment }\end{array}$ & $\begin{array}{l}\text { Collective } \\
\text { payment }\end{array}$ & $\begin{array}{l}\text { Crop-price } \\
\text { premium } \\
\text { payment }\end{array}$ \\
\hline $\begin{array}{l}\text { Set of best private } \\
\text { strategies }\end{array}$ & $X_{f i} \in\{0,1,2\}$ & $X_{f i} \in\{0,1,2,3,4\}$ & $X_{f i} \in\{0,1,2,3\}$ & $X_{f i} \in\{0,1,2,3\}$ \\
\hline Set of nash & $\{0,0,0,0\}$ & $\{0,0,0,0\}\{0,1,3,3\}$ & $\{0,0,0,0\}\{0,1,3,3\}$ & $\{0,0,0,0\}\{0,1,3,3\}$ \\
equilibria & $\{1,2,2,2\}$ & $\{0,1,2,4\}\{0,0,3,4\}$ & $\{0,2,2,3\}\{1,2,2,2\}$ & $\{0,2,2,3\}\{1,2,2,2\}$ \\
& & $\{0,2,2,3\}\{1,2,2,2\}$ & $\{1,1,2,3\}$ & $\{1,1,2,3\}$ \\
& & $\{1,1,2,3\}\{1,1,1,4\}$ & & \\
\hline
\end{tabular}


Annex 5 socio-demographic data for control and treatment groups.

*Monthly income is reported for a subsample because no data was available for the whole sample.

\begin{tabular}{|c|c|c|c|c|c|c|c|c|c|}
\hline \multirow[t]{2}{*}{ Treatment } & Men & Age & \multicolumn{6}{|c|}{ Education (\%) } & \multirow{2}{*}{$\begin{array}{l}\text { Monthly } \\
\text { income* }\end{array}$} \\
\hline & & & None & $\begin{array}{c}\text { Incomplete } \\
\text { primary }\end{array}$ & $\begin{array}{c}\text { Complete } \\
\text { primary }\end{array}$ & $\begin{array}{c}\text { Incomplete } \\
\text { high } \\
\text { school }\end{array}$ & $\begin{array}{l}\text { Complete } \\
\text { high- } \\
\text { school }\end{array}$ & $\begin{array}{l}\text { Tecnician } \\
\text { or } \\
\text { superior }\end{array}$ & \\
\hline \multirow{2}{*}{$\begin{array}{l}\text { Control } \\
\text { group n } \\
=52\end{array}$} & \multirow[t]{2}{*}{54.00} & \multirow[t]{2}{*}{48.4} & \multirow[t]{2}{*}{12.00} & \multirow[t]{2}{*}{40.00} & \multirow[t]{2}{*}{16.00} & \multirow[t]{2}{*}{14.00} & \multirow[t]{2}{*}{6.00} & \multirow[t]{2}{*}{12} & $\$ 498.750$ \\
\hline & & & & & & & & & $(n=36)$ \\
\hline \multirow{2}{*}{$\begin{array}{l}\text { Individual } \\
\text { Payment } \mathrm{n} \\
=52\end{array}$} & \multirow[t]{2}{*}{46.15} & \multirow[t]{2}{*}{45.5} & \multirow[t]{2}{*}{11.54} & \multirow[t]{2}{*}{25.00} & \multirow[t]{2}{*}{23.08} & \multirow[t]{2}{*}{15.38} & \multirow[t]{2}{*}{15.38} & \multirow[t]{2}{*}{9.62} & $\$ 659.230$ \\
\hline & & & & & & & & & $(n=39)$ \\
\hline \multirow{2}{*}{$\begin{array}{l}\text { Collective } \\
\text { Payment } \mathrm{n} \\
=52\end{array}$} & \multirow[t]{2}{*}{53.85} & \multirow[t]{2}{*}{49.07} & \multirow[t]{2}{*}{9.62} & \multirow[t]{2}{*}{26.92} & \multirow[t]{2}{*}{17.31} & \multirow[t]{2}{*}{9.62} & \multirow[t]{2}{*}{17.31} & \multirow[t]{2}{*}{19.23} & $\$ 681.227$ \\
\hline & & & & & & & & & $(n=44)$ \\
\hline \multirow{2}{*}{$\begin{array}{l}\text { Premium } \\
\text { price } n=52\end{array}$} & \multirow[t]{2}{*}{63.46} & \multirow[t]{2}{*}{49.28} & \multirow[t]{2}{*}{17.31} & \multirow[t]{2}{*}{30.77} & \multirow[t]{2}{*}{19.23} & \multirow[t]{2}{*}{11.54} & 13.46 & 7.69 & $\$ 560.950$ \\
\hline & & & & & & & & & $(n=40)$ \\
\hline $\begin{array}{l}\text { Individual } \\
\text { payment by }\end{array}$ & 52.63 & 51.7 & 15.79 & 15.79 & 31.58 & 15.79 & 10.53 & 10.53 & $\$ 479.231$ \\
\hline $\begin{array}{l}\text { voting } \mathrm{n} \\
=20\end{array}$ & & & & & & & & & $(n=13)$ \\
\hline $\begin{array}{l}\text { Collective } \\
\text { payment by }\end{array}$ & 56.25 & 51.2 & 12.50 & 28.12 & 15.62 & 12.50 & 28.12 & 3.12 & $\$ 428.125$ \\
\hline $\begin{array}{l}\text { voting } \\
n=32\end{array}$ & & & & & & & & & $(n=24)$ \\
\hline
\end{tabular}


Annex 6. Histograms of motivations per type of payment in the experiment.
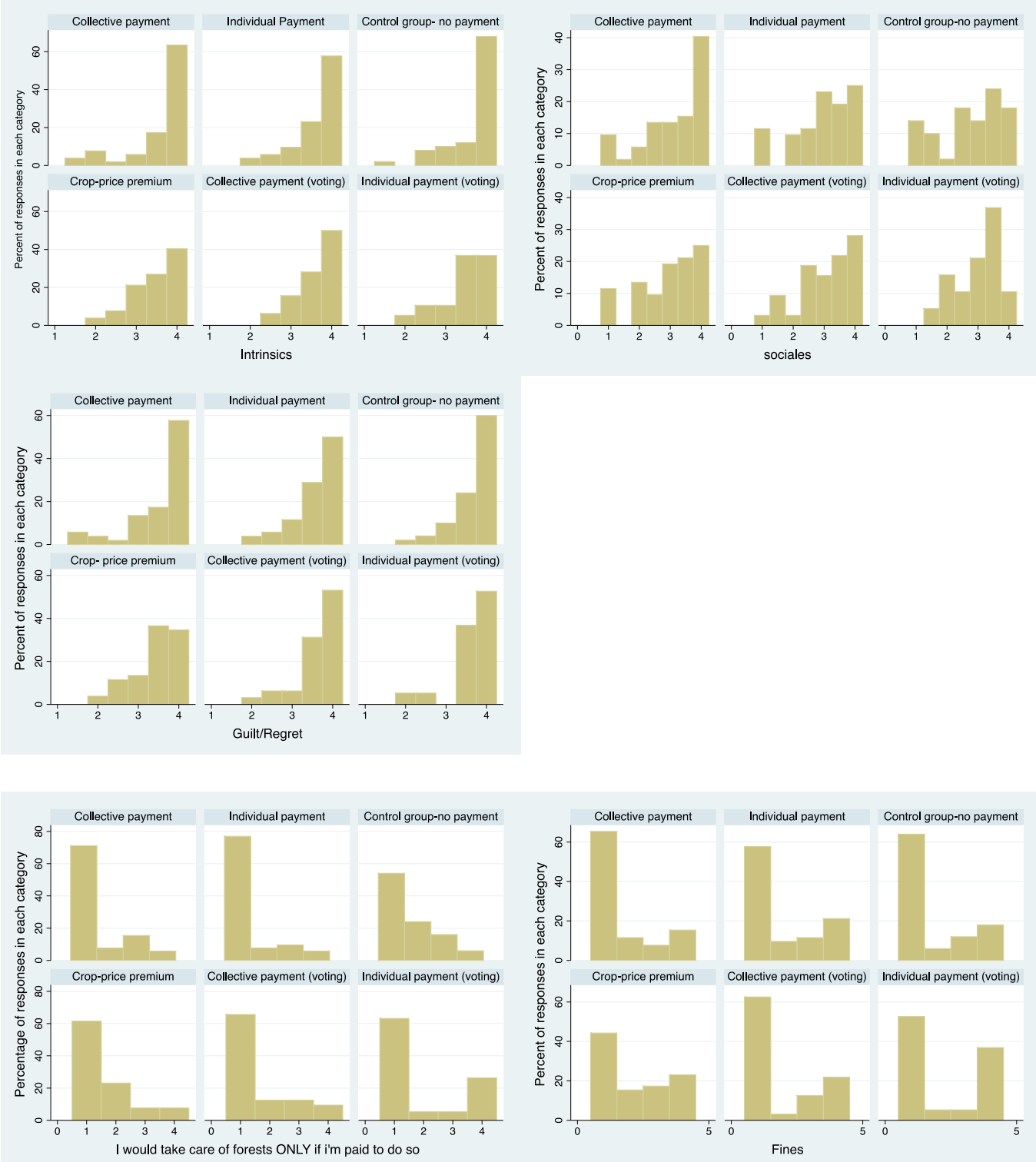
Annex 7 Robustness check for each type of motivation including different specifications.

\begin{tabular}{|c|c|c|c|c|c|c|c|c|c|c|c|c|c|c|c|}
\hline & (1) & (2) & (3) & (4) & (5) & (6) & (7) & (8) & (9) & (10) & (11) & (12) & (13) & (14) & (15) \\
\hline VARIABLES & Intrinsics & Intrinsics & Intrinsics & Intrinsics & Intrinsics & Guilt/Regret & Guilt/Regret & Guilt/Regret & Guilt/Regret & Guilt/Regret & Socials & Socials & Socials & Socials & Socials \\
\hline \multirow[t]{2}{*}{ Collective payment } & -0.206 & -0.215 & -0.272 & -0.304 & -0.372 & -0.259 & -0.274 & -0.307 & -0.337 & -0.377 & $0.795^{\star *}$ & $0.780^{\star *}$ & $0.832^{\star *}$ & $0.831^{* *}$ & $1.021^{* \star *}$ \\
\hline & $(0.414)$ & $(0.417)$ & $(0.426)$ & $(0.438)$ & $(0.445)$ & $(0.394)$ & $(0.400)$ & $(0.403)$ & $(0.405)$ & $(0.413)$ & $(0.362)$ & $(0.363)$ & $(0.367)$ & $(0.367)$ & $(0.376)$ \\
\hline \multirow[t]{2}{*}{ Individual payment } & -0.339 & -0.379 & -0.396 & -0.529 & -0.576 & -0.395 & -0.327 & -0.333 & -0.403 & -0.424 & 0.332 & 0.375 & 0.453 & 0.440 & 0.602 \\
\hline & $(0.403)$ & $(0.407)$ & $(0.414)$ & $(0.424)$ & $(0.427)$ & $(0.382)$ & $(0.386)$ & $(0.387)$ & $(0.391)$ & $(0.393)$ & $(0.349)$ & $(0.356)$ & $(0.360)$ & $(0.361)$ & $(0.371)$ \\
\hline \multirow[t]{2}{*}{ Premium price payment } & $-0.965^{\star \star}$ & $-0.916^{\star *}$ & $-0.891^{\star \star}$ & $-0.958^{\star \star}$ & $-0.999^{\star \star}$ & $-0.921^{\star \star}$ & $-0.919^{\star \star}$ & $-0.943^{* *}$ & $-0.999^{\star \star \star \star}$ & $-1.019^{\star \star \star}$ & 0.310 & 0.331 & 0.421 & 0.409 & 0.558 \\
\hline & $(0.391)$ & $(0.393)$ & $(0.399)$ & $(0.410)$ & $(0.412)$ & $(0.374)$ & $(0.375)$ & $(0.379)$ & $(0.382)$ & $(0.383)$ & $(0.351)$ & $(0.351)$ & $(0.355)$ & $(0.354)$ & $(0.362)$ \\
\hline \multirow[t]{2}{*}{ Collective by voting } & -0.551 & -0.557 & -0.470 & -0.445 & -0.500 & -0.228 & -0.309 & -0.294 & -0.300 & -0.341 & 0.498 & 0.412 & 0.551 & 0.578 & $0.757^{*}$ \\
\hline & $(0.442)$ & $(0.444)$ & $(0.455)$ & $(0.469)$ & $(0.474)$ & $(0.436)$ & $(0.441)$ & $(0.449)$ & $(0.451)$ & $(0.459)$ & $(0.398)$ & $(0.402)$ & $(0.409)$ & $(0.410)$ & $(0.418)$ \\
\hline \multirow[t]{2}{*}{ Individual by voting } & $-0.997^{\star *}$ & $-1.045^{\star *}$ & $-1.166^{* *}$ & $-1.226^{\star \star}$ & $-1.229^{\star *}$ & -0.188 & -0.191 & -0.211 & -0.290 & -0.299 & 0.258 & 0.200 & 0.274 & 0.236 & 0.328 \\
\hline & $(0.504)$ & $(0.509)$ & $(0.522)$ & $(0.531)$ & $(0.531)$ & $(0.513)$ & $(0.517)$ & $(0.523)$ & $(0.526)$ & $(0.527)$ & $(0.448)$ & $(0.456)$ & $(0.465)$ & $(0.462)$ & $(0.468)$ \\
\hline \multirow[t]{2}{*}{ Sex } & & $-0.437 *$ & -0.410 & -0.279 & -0.251 & & -0.0551 & -0.0320 & 0.00664 & 0.0229 & & -0.253 & -0.282 & -0.227 & -0.273 \\
\hline & & $(0.250)$ & $(0.256)$ & $(0.262)$ & $(0.264)$ & & $(0.242)$ & $(0.245)$ & $(0.247)$ & $(0.249)$ & & $(0.226)$ & $(0.230)$ & $(0.232)$ & $(0.233)$ \\
\hline \multirow[t]{2}{*}{ Age } & & 0.00605 & 0.0124 & 0.0110 & 0.00823 & & $0.0264^{\star \star \star}$ & $0.0248^{\star \star \star}$ & $0.0246^{\star \star \star}$ & $0.0231^{\star *}$ & & $0.0226^{\star \star \star}$ & $0.0216^{\star \star \star}$ & $0.0207^{\star *}$ & $0.0276^{\star \star \star}$ \\
\hline & & $(0.00769)$ & $(0.00910)$ & $(0.00931)$ & $(0.00982)$ & & $(0.00762)$ & $(0.00903)$ & $(0.00904)$ & $(0.00949)$ & & $(0.00713)$ & $(0.00815)$ & $(0.00815)$ & $(0.00877)$ \\
\hline \multirow[t]{2}{*}{ incomplete } & & & 0.458 & 0.675 & 0.668 & & & -0.364 & -0.253 & -0.260 & & & 0.0223 & 0.113 & 0.162 \\
\hline & & & $(0.457)$ & $(0.466)$ & $(0.466)$ & & & $(0.470)$ & $(0.474)$ & $(0.475)$ & & & $(0.415)$ & $(0.420)$ & $(0.422)$ \\
\hline \multirow[t]{2}{*}{ Primary school complete } & & & -0.112 & 0.272 & 0.305 & & & -0.437 & -0.322 & -0.307 & & & 0.220 & 0.324 & 0.306 \\
\hline & & & $(0.396)$ & $(0.411)$ & $(0.412)$ & & & $(0.436)$ & $(0.441)$ & $(0.442)$ & & & $(0.371)$ & $(0.377)$ & $(0.380)$ \\
\hline \multirow[t]{2}{*}{ Highschool not finished } & & & 0.608 & 0.742 & 0.696 & & & -0.469 & -0.445 & -0.476 & & & 0.272 & 0.336 & 0.444 \\
\hline & & & $(0.532)$ & $(0.539)$ & $(0.541)$ & & & $(0.553)$ & $(0.552)$ & $(0.556)$ & & & $(0.477)$ & $(0.479)$ & $(0.481)$ \\
\hline \multirow[t]{2}{*}{ Highschool finished } & & & -0.180 & -0.00440 & -0.00837 & & & -0.293 & -0.216 & -0.221 & & & -0.345 & -0.282 & -0.267 \\
\hline & & & $(0.495)$ & $(0.499)$ & $(0.500)$ & & & $(0.519)$ & $(0.522)$ & $(0.522)$ & & & $(0.460)$ & $(0.461)$ & $(0.464)$ \\
\hline \multirow[t]{2}{*}{$\begin{array}{l}\text { More than highschool } \\
\text { (university, graduate) }\end{array}$} & & & $1.152^{\star *}$ & $1.463^{\star \star}$ & $1.482^{\star *}$ & & & -0.110 & -0.0261 & -0.0199 & & & 0.182 & 0.261 & 0.292 \\
\hline & & & $(0.573)$ & $(0.586)$ & $(0.587)$ & & & $(0.548)$ & $(0.549)$ & $(0.550)$ & & & $(0.491)$ & $(0.491)$ & $(0.492)$ \\
\hline \multirow[t]{2}{*}{ Has cut down the forest? } & & & & $-1.208^{\star \star \star}$ & $-1.230^{\star \star *}$ & & & & $-0.489^{\star}$ & $-0.501^{*}$ & & & & $-0.421^{*}$ & -0.399 \\
\hline & & & & $(0.275)$ & $(0.277)$ & & & & $(0.271)$ & $(0.272)$ & & & & $(0.251)$ & $(0.252)$ \\
\hline \multirow[t]{2}{*}{$\begin{array}{l}\text { Want children to become } \\
\text { farmers? }\end{array}$} & & & & & 0.261 & & & & & 0.144 & & & & & $-0.595^{* *}$ \\
\hline & & & & & $(0.290)$ & & & & & $(0.281)$ & & & & & $(0.268)$ \\
\hline Observations & 257 & 257 & 257 & 257 & 257 & 257 & 257 & 257 & 257 & 257 & 257 & 257 & 257 & 257 & 257 \\
\hline
\end{tabular}


Annex 7. Cont'

\begin{tabular}{|c|c|c|c|c|c|c|c|c|c|c|}
\hline & (16) & (17) & (18) & (19) & (20) & (21) & (22) & (23) & (24) & (25) \\
\hline VARIABLES & Payments & Payments & Payments & Payments & Payments & Fines & Fines & Fines & Fines & Fines \\
\hline \multirow[t]{2}{*}{ Collective payment } & -0.553 & -0.552 & -0.371 & -0.360 & -0.349 & -0.125 & -0.152 & 0.0594 & 0.0554 & -0.0720 \\
\hline & $(0.401)$ & (0.405) & (0.418) & (0.418) & $(0.427)$ & $(0.404)$ & (0.406) & (0.424) & $(0.425)$ & $(0.436)$ \\
\hline \multirow[t]{2}{*}{ Individual payment } & $-0.868^{\star \star}$ & $-0.741^{*}$ & -0.707 & -0.676 & -0.668 & 0.233 & 0.306 & 0.374 & 0.412 & 0.319 \\
\hline & $(0.420)$ & $(0.426)$ & $(0.436)$ & $(0.438)$ & $(0.442)$ & $(0.394)$ & $(0.397)$ & $(0.414)$ & $(0.417)$ & $(0.424)$ \\
\hline \multirow[t]{2}{*}{ Premium price payment } & -0.268 & -0.313 & -0.297 & -0.262 & -0.253 & 0.612 & 0.545 & 0.556 & 0.570 & 0.492 \\
\hline & $(0.379)$ & $(0.385)$ & $(0.395)$ & $(0.398)$ & $(0.404)$ & $(0.381)$ & $(0.384)$ & $(0.400)$ & $(0.401)$ & $(0.406)$ \\
\hline \multirow[t]{2}{*}{ Collective by voting } & -0.313 & -0.350 & -0.127 & -0.118 & -0.106 & 0.126 & 0.0839 & 0.280 & 0.270 & 0.151 \\
\hline & $(0.450)$ & $(0.456)$ & $(0.480)$ & $(0.482)$ & $(0.490)$ & $(0.459)$ & $(0.462)$ & $(0.484)$ & $(0.485)$ & $(0.493)$ \\
\hline \multirow[t]{2}{*}{ Individual by voting } & 0.0672 & 0.0645 & 0.348 & 0.399 & 0.400 & 0.660 & 0.663 & 0.842 & 0.873 & 0.848 \\
\hline & $(0.553)$ & $(0.560)$ & $(0.578)$ & $(0.580)$ & $(0.580)$ & $(0.537)$ & $(0.542)$ & $(0.557)$ & $(0.558)$ & $(0.557)$ \\
\hline \multirow[t]{2}{*}{ Sex } & & $0.754^{\star \star \star}$ & $0.736^{\star \star \star}$ & $0.703^{\star \star}$ & $0.699^{\star *}$ & & $0.578^{\star \star}$ & $0.585^{\star \star}$ & $0.561^{\star *}$ & $0.612^{\star *}$ \\
\hline & & $(0.273)$ & $(0.281)$ & $(0.284)$ & $(0.286)$ & & $(0.254)$ & $(0.266)$ & $(0.267)$ & $(0.271)$ \\
\hline \multirow[t]{2}{*}{ Age } & & 0.0110 & -0.00748 & -0.00696 & -0.00645 & & 0.00330 & $-0.0204 * *$ & $-0.0195 * *$ & $-0.0241 * *$ \\
\hline & & $(0.00823)$ & $(0.0101)$ & $(0.0102)$ & $(0.0109)$ & & $(0.00772)$ & $(0.00943)$ & $(0.00947)$ & $(0.0101)$ \\
\hline \multirow[t]{2}{*}{ Primary school incomplete } & & & $-1.192^{\star *}$ & $-1.239^{\star *}$ & $-1.236^{\star *}$ & & & $-1.229 * * *$ & $-1.284 * * *$ & $-1.331 * * *$ \\
\hline & & & $(0.492)$ & $(0.496)$ & $(0.497)$ & & & $(0.452)$ & $(0.457)$ & $(0.459)$ \\
\hline \multirow[t]{2}{*}{ Primary school complete } & & & -0.456 & -0.508 & -0.508 & & & $-1.090^{* * * *}$ & $-1.165 * * *$ & $-1.155^{* * * *}$ \\
\hline & & & $(0.414)$ & $(0.420)$ & $(0.420)$ & & & $(0.409)$ & $(0.418)$ & $(0.420)$ \\
\hline \multirow[t]{2}{*}{ Highschool not finished } & & & $-0.967 *$ & $-0.981 *$ & $-0.971^{*}$ & & & $-2.348^{* * *}$ & $-2.370 * * *$ & $-2.488^{* * * *}$ \\
\hline & & & $(0.567)$ & $(0.567)$ & $(0.571)$ & & & $(0.570)$ & $(0.571)$ & $(0.581)$ \\
\hline \multirow[t]{2}{*}{ Highschool finished } & & & $-1.726^{\star \star \star}$ & $-1.767^{\star \star \star}$ & $-1.764^{\star \star \star}$ & & & $-2.228 * * *$ & $-2.257^{* * *}$ & $-2.311^{* * *}$ \\
\hline & & & $(0.602)$ & (0.606) & $(0.606)$ & & & $(0.545)$ & $(0.546)$ & $(0.549)$ \\
\hline \multirow[t]{2}{*}{$\begin{array}{l}\text { More than highschool } \\
\text { (university, graduate) }\end{array}$} & & & $-2.062^{\star \star \star}$ & $-2.080^{\star * *}$ & $-2.079^{\star \star \star}$ & & & $-2.507 * * * *$ & $-2.544 * * *$ & $-2.570^{* * *}$ \\
\hline & & & $(0.691)$ & $(0.691)$ & $(0.691)$ & & & $(0.642)$ & $(0.645)$ & $(0.647)$ \\
\hline \multirow[t]{2}{*}{ Has cut down the forest? } & & & & 0.236 & 0.239 & & & & 0.271 & 0.242 \\
\hline & & & & $(0.296)$ & $(0.298)$ & & & & $(0.282)$ & $(0.284)$ \\
\hline \multirow[t]{2}{*}{$\begin{array}{l}\text { Want children to become } \\
\text { farmers? }\end{array}$} & & & & & -0.0429 & & & & & 0.418 \\
\hline & & & & & $(0.323)$ & & & & & $(0.310)$ \\
\hline Observations & 257 & 257 & 257 & 257 & 257 & 257 & 257 & 257 & 257 & 257 \\
\hline
\end{tabular}

Annex 8: Success rate across experimental stages.

\begin{tabular}{|l|c|c|}
\hline & Rate of success stage 1 & Rate of success stage 2 \\
\hline Control group $(\mathrm{CG})$ & $90 \%$ & $83 \%$ \\
\hline Individual payment & $87 \%$ & $89,4 \%$ \\
\hline Collective payment & $89,1 \%$ & $89,4 \%$ \\
\hline Crop-price premium & $83,1 \%$ & $72,3 \%$ \\
\hline Individual by voting & $56 \%$ & $80 \%$ \\
\hline Collective by voting & $85 \%$ & $92,5 \%$ \\
\hline
\end{tabular}

